\title{
A regulamentação do uso da internet no Brasil pela Lei no $12.965 / 2014$ e a proteção dos dados e dos registros pessoais
}

\author{
The Internet regulation in Brazil and the protection of personal data \\ and records: Statute $n$ o 12.965/2014
}

\author{
ANTONIA ESPÍNDOLA LONGONI KLEE
}

\section{RESUMO}

O artigo analisa a regulamentação do uso da internet no Brasil pela Lei no 12.965/2014 e a proteção de dados e de registros pessoais. Para uma melhor compreensão, aborda a proteção de dados e de registros pessoais como um direito fundamental do indivíduo, previsto na Constituição da República de 1988. Examina o direito à proteção de dados e de registros pessoais como um direito do consumidor previsto no Código de Defesa do Consumidor. Aborda a atualização do Código de Defesa do Consumidor pelo Projeto de Lei do Senado no 281/2012, que trata de comércio eletrônico, ainda em tramitação, especificamente no que se refere à proteção de dados e de registros pessoais. Da mesma forma, apresenta a regulamentação da proteção de dados e de registros pessoais pela Lei $\mathrm{n}^{\mathrm{o}}$ 12.965/2014, que estabelece princípios, garantias, direitos e deveres para o uso da internet no Brasil. Por fim, avalia o Anteprojeto de Lei de Proteção de Dados.

Palavras-chave: Proteção de dados pessoais. Marco civil da Internet no Brasil. Código de Defesa do Consumidor. Projeto de Lei do Senado no 281/2012. Comércio eletrônico.

\begin{abstract}
The paper analyzes the Internet regulation in Brazil by Statute $\mathrm{n}$ - 12.965/2014 and the protection of personal data and personal records. For a better understanding, it addresses the protection of personal data and personal records as a fundamental right of the individual, provided in the Constitution of 1988. The paper examines the right to protection of personal data and personal records as a consumer right under the Consumer Protection Code. It discusses the updating of the Consumer Protection Code by Senate Bill no 281/2012 that regulates e-commerce, specifically with regard to data protection and personal records protection. Likewise, it presents the regulation of data protection and personal records protection by Statute $\mathrm{n}^{\mathrm{O}} 12.965 / 2014$, which establishes principles, guarantees, rights and duties for the use of the Internet in Brazil. Finally, it examines the Brazilian Draft Law on Data Protection.
\end{abstract}

Keywords: Protection of Personal Data. Internet Civil Benchmark in Brazil. Code of Consumer Protection. Senate Bill no $281 / 2012$. Electronic Commerce.

\footnotetext{
a Doutora e Mestre em Direito pela Universidade Federal do Rio Grande do Sul (UFRGS). Especialista em Direito Internacional pela UFRGS. Advogada. Professora convidada do Curso de Especialização Lato Sensu em Direito do Consumidor e Direitos Fundamentais da UFRGS. Diretora do Brasilcon. Membro do IARGS, do IBDCivil, do IDP, da Asadip, do Conselho Municipal de Defesa do Consumidor do Município de Porto Alegre e da Comissão Especial de Defesa do Consumidor da OAB/RS. E-mail: <antoniaklee@hotmail.com>.
} 


\section{INTRODUÇÃO}

Segundo demonstra Mendes, desde a segunda metade do século XX, poucos conceitos jurídicos sofreram tanta transformação como o conceito de privacidade ${ }^{1}$. Por isso, é necessário examiná-lo em conjunto com o princípio da proteção dos dados e dos registros pessoais.

A expressão "dados" é a tradução da palavra latina e também inglesa data, significando "informações". "Usualmente, dados são informações. Tecnicamente, são informações que passaram por algum tipo de tratamento, ainda que por uma simples coleta, por meio eletrônico ou não" ${ }^{2}$. Dessa maneira, sigilo de dados significa sigilo de informações tratadas, de forma informatizada ou não. E mais: é o sigilo de qualquer informação que tiver caráter nominativo, possibilitando identificar direta ou indiretamente a pessoa referida ${ }^{3}$. A inviolabilidade é conferida com relação à utilização desleal das informações.

Doneda afirma que:

[...] a disciplina de proteção de dados pessoais desenvolveu-se a partir da aplicação de determinadas concepções do direito à privacidade e da proteção da pessoa em face do desenvolvimento tecnológico. A própria expressão 'proteção de dados' não reflete fielmente seu âmago, pois é resultado de um processo de desenvolvimento do qual participaram diversos interesses em jogo - não são os dados que são protegidos, porém a pessoa à qual tais dados se referem ${ }^{4}$.

Os dados pessoais dos indivíduos são coletados constantemente, estejam as pessoas na posição de contribuinte, de paciente, de trabalhador, de beneficiário de programas sociais ou de consumidor ${ }^{5}$. A vigilância, no mundo informatizado e globalizado, é cotidiana. Por isso, a utilização em massa dos dados pessoais por órgãos públicos e privados, por meio do avanço da tecnologia da informação, apresenta novos desafios à proteção do direito à privacidade ${ }^{6} \mathrm{e}$ à proteção dos direitos dos consumidores.

A combinação de diversas técnicas automatizadas permite a obtenção de uma grande quantidade de informação sobre as pessoas e a elaboração de perfis virtuais, que passam a fundamentar a tomada de decisões econômicas, políticas e sociais ${ }^{7}$. No contexto do avanço das ferramentas tecnológicas, destacam-se a criação e o desenvolvimento da internet, estrutura de rede aberta de computadores que possibilita a transmissão e o armazenamento de um enorme volume de informação ${ }^{8}$.
A principal característica da internet é a de ser uma rede aberta, que possibilita a difusão e o aperfeiçoamento da tecnologia de controle e monitoramento ${ }^{9}$, que pode significar a restrição da liberdade da pessoa. Em função das modificações sociais e da evolução tecnológica acarretadas pela utilização da internet de maneira globalizada, a discussão sobre os danos decorrentes do processamento e da transmissão de dados na sociedade não se restringe apenas à ameaça do poder do Estado, mas também à atuação, muitas vezes inconstitucional, do setor privado, que utiliza os dados pessoais colhidos para atingir objetivos econômicos ${ }^{10}$.

Sabe-se que as informações sobre as pessoas que se relacionam social e juridicamente são coletadas mesmo sem o conhecimento nem o consentimento do indivíduo. A ameaça de violação dos direitos da personalidade vem das empresas que coletam, armazenam, processam e transmitem dados de seus clientes e consumidores para outras empresas e outros órgãos estatais. A tecnologia da informação permite transformar dados parciais e dispersos em informações em massa e organizadas. Nesse contexto, os riscos ao direito da personalidade das pessoas aumentam ${ }^{11}$.

A violação do direito de privacidade na sociedade de informação passa a significar, por exemplo, o risco do uso indevido de dados pessoais, da classificação dos indivíduos por características comuns, como o perfil de consumo, de imposição de comportamentos padronizados e da discriminação dos cidadãos $^{12}$. O ordenamento jurídico brasileiro pode oferecer instrumentos e conceitos aptos à proteção de dados, desde que interpretados à luz das modificações sociais e tecnológicas decorrentes da sociedade de informação e respeitados os princípios fundamentais constantes da Constituição ${ }^{13}$.

A proteção de dados deve estar embasada nos princípios constitucionais da dignidade da pessoa humana, do respeito à vida privada, à privacidade e à liberdade da pessoa, porque são informações que dizem respeito à sua intimidade. $\mathrm{O}$ valor supremo da dignidade da pessoa humana limita o alcance de qualquer regramento jurídico e justifica a existência e a proteção dos direitos da personalidade ${ }^{14}$.

Os valores da personalidade que compõem direta e indiretamente o âmbito da vida privada, tais como o nome, a imagem, os escritos, a palavra, a voz, o domicílio, a privacidade, a intimidade, a boa fama, a respeitabilidade, são explicitamente regulados pelo Código Civil, na Parte Geral, Livro I - Das Pessoas, Capítulo II - Dos direitos da personalidade, arts. 11 a $21^{15}$.

A vida privada - ao lado da intimidade, da honra e da imagem - foi acolhida no art. 5ํㅡ, X, da Constituição, 
como direito fundamental inviolável. A evolução da tecnologia determinou a inclusão da análise dos riscos decorrentes da utilização irresponsável da informática para os direitos fundamentais ao estudo do direito à intimidade e à vida privada. Isso porque a tecnologia pode violar o direito à intimidade, se utilizada sem limites. Essas limitações devem ser estabelecidas pelo Estado, por meio de legislação. O direito ao respeito da vida privada compreende a proteção de dados pessoais ${ }^{16}$.

Os direitos sem os quais o ser humano ou a pessoa jurídica não alcança o objetivo imanente à sua natureza - os direitos da personalidade - são inerentes à pessoa desde a sua concepção, essenciais e vitalícios, extrapatrimoniais e relativamente indisponíveis, irrenunciáveis, imprescritíveis e oponíveis erga omnes $^{17}$. É inerente à pessoa o direito de não revelar dados pessoais reservados, de não dar a conhecer aspectos e hábitos, comportamentos e condutas ${ }^{18}$. Um dos direitos da personalidade é o direito ao resguardo, ao isolamento, à solidão, é o direito de ser deixado só ${ }^{19}$, direito à privacidade, ou à vida privada.

Nas palavras de Jabur, "a dignidade humana não se afirma nem se sustém senão sob o influxo dos direitos personalíssimos"20. Isto é, são eles que justificam a importância do princípio da dignidade da pessoa humana, constante do art. $1^{\circ}$, III, da Constituição, como um dos fundamentos do Estado Democrático de Direito $^{21}$.

A proteção dos dados e dos registros pessoais tem sido debatida no cenário jurídico nacional, principalmente depois da entrada em vigor da Lei no 12.965 , de 23 de abril de 2014, que estabelece princípios, garantias, direitos e deveres para o uso da internet no Brasil. Com a entrada em vigor desse diploma legal, conhecido como o "marco civil da internet", em 23 de junho de 2014, os aplicadores do Direito devem ter o cuidado de não retroceder nos direitos e nas garantias alcançados pelo ordenamento jurídico brasileiro ao aplicar essa legislação. Por isso, sugere-se uma aplicação conjunta, um "diálogo das fontes" 22 entre o Código de Defesa do Consumidor e a Lei no $12.965 / 2014$, à luz do princípio da dignidade da pessoa humana, assegurado pela Constituição, bem como o princípio da vulnerabilidade do consumidor, garantido pelo CDC (art. 4ํㅡ, I), e baseada no princípio da proibição do retrocesso dos direitos fundamentais.

Assim, o presente artigo visa a examinar o direito à proteção dos dados e dos registros pessoais refletindo sobre a regulamentação de seu uso pela Lei $\mathrm{n}^{\mathrm{o}}$ 12.965/2014 bem como à luz do Código de Defesa do Consumidor e do Projeto de
Lei do Senado no 281/2012, que dispõe sobre o comércio eletrônico. Também, será realizada uma breve análise do Anteprojeto de Lei de Proteção de Dados Pessoais ${ }^{23}$, que ainda está sendo debatido.

\section{A PROTEÇÃO DOS DADOS E DOS REGISTROS PESSOAIS NO ORDENAMENTO JURÍDICO BRASILEIRO}

O avanço da informática fez que a sociedade reclamasse um sistema mais efetivo de proteção de sua intimidade, em função da fragilidade dos instrumentos de garantia existentes. A partir da promulgação da Constituição de República de 1988, houve um reconhecimento de um "direito geral à intimidade e à vida privada", explicitado por disposições que atualizam o sistema de proteção dos direitos fundamentais, sobretudo do direito à intimidade $^{24}$.

Propõe-se uma análise da proteção dos dados e dos registros pessoais como um direito fundamental previsto na Constituição e no Código de Defesa do Consumidor.

\subsection{A proteção dos dados e dos registros pessoais como um direito fundamental}

A Constituição dispôs sobre a proteção da intimidade no art. 5-, $\mathrm{X}^{25}$, ao prever o princípio da inviolabilidade da intimidade e da vida privada, de uma forma geral, e, a seguir, no inc. XII do mesmo $\operatorname{artigo}^{26}$, ao prever o princípio da inviolabilidade dos dados. Em outras palavras, a Constituição tratou do assunto da proteção dos dados pessoais na esfera do direito fundamental à intimidade, ao estatuir a inviolabilidade do sigilo dos dados (art. 5으, XII) e o habeas data (art. 5ํ, XLLII), mas não dispôs sobre os limites de compreensão do sigilo de dados ${ }^{27}$. Também, no art. 5o, $\S 1$ 1a a Constituição dispôs que "as normas definidoras dos direitos e garantias fundamentais têm aplicação imediata". A novidade trazida pela Constituição apareceu de uma forma mais completa no inc. LXXII do art. 5, ao tratar do habeas data ${ }^{28}$.

O habeas data tem por objeto a proteção dos indivíduos contra: a) os usos abusivos e nocivos de registros pessoais coletados por meios fraudulentos, desleais ou ilícitos; b) a introdução dos dados sensíveis nos registros; c) a conservação de dados falsos ou com fins diversos dos autorizados em $\mathrm{le}^{29}$. O habeas data foi regulamentado pela Lei no 9.507/1997, que disciplina o direito de acesso a informações e o seu rito processual $^{30}$. Destina-se a: 
assegurar o conhecimento de informações relativas à pessoa do impetrante constantes de registro ou banco de dados de entidades governamentais ou de caráter público; retificar dados, quando não se prefira fazê-lo por processo sigiloso, judicial ou administrativo; e anotar nos assentamentos do interessado de contestação ou explicação sobre dado verdadeiro, porém justificável, ou que esteja sob pendência judicial ou amigável ${ }^{31}$.

Sabe-se que Warren e Brandeis, ao escreverem o artigo The Right to Privacy, redefiniram o sentido de intimidade, ao alertarem para os riscos que as novas tecnologias, especialmente no campo fotográfico, traziam à privacidade ${ }^{32}$.

A capacidade de coleta, de armazenamento e de processamento dos dados ampliaram as possibilidades de invasão na intimidade das pessoas, sejam elas famosas ou não. O Estado passou a utilizar os recursos do computador na busca de otimização e de aperfeiçoamento de seus planos e projetos sociais, econômicos e políticos que, sob o ponto de vista do indivíduo, ferem a sensibilidade dos cidadãos no seu "direito a ser deixado só" 33 . Sampaio afirma: "Informações quanto ao grau de escolaridade, poder aquisitivo, história clínica e uso de medicamentos certamente violariam aquele direito (de ser deixado em paz)" ${ }^{\prime 34}$. E o autor ressalta:

Mas não apenas o Estado se beneficiaria do computador: a própria textura social não prescindirá do novo invento para aperfeiçoar seus mecanismos de atuação e interação, de modo a potencializar um conjunto de operações até então dispendiosas ou mesmo impensáveis. $\mathrm{O}$ processamento de contas bancárias, o controle de créditos, as reservas de hotéis ou aviões, tudo se tornou mais fácil e mais ágil ${ }^{35}$.

A sociedade da informação nasce com o progresso técnico, que permite armazenar, guardar, modificar, encontrar e comunicar "informação", sem importar a maneira de se fazer isso, sem haver limite de espaço, tempo e volume ${ }^{36}$. Lisboa menciona que a revolução informacional, decorrente do avanço tecnológico, permite o "acesso aos bens intangíveis ou incorpóreos" ${ }^{37}$. Segundo o autor, na sociedade da informação valorizam-se os contratos de fornecimento de serviços $^{38}$, muitos deles celebrados a distância e por meios eletrônicos ${ }^{39}$. Os dados pessoais são bens intangíveis e incorpóreos que podem ser objeto de contratos de prestação de serviços, por isso há a necessidade de regulamentar a sua proteção.

Ascensão, por seu turno, menciona que há certo inchaço do termo "sociedade de informação":
[...] o que há é a sociedade da comunicação integral, e não a sociedade da informação. O conteúdo da mensagem transmitida não é necessariamente informação - ou só o é se entendermos informação em sentido de tal modo lato que lhe faz perder toda a precisão. Quem acede a uma página erótica ou pratica um jogo não se está a informar. Todavia, é também verdade que, paralelamente ao avanço destes meios, se desenvolve um tipo de sociedade em que a informação passa a desempenhar um papel muito mais decisivo que anteriormente. $\mathrm{O}$ salto qualitativo no domínio da informação permite a alguns qualificá-la como um novo factor de produção, que distinguiria ainda mais radicalmente os países que a possuem dos que a não possuem. [...]

Podemos exprimi-lo de maneira mais radical: quem domina a informação domina o mundo. [...]

A sociedade da informação é assim uma sociedade que brota tendo ínsita uma contradição fundamental. Nasce sob a égide de uma comunicação universal e nesse sentido igualitária, mas na base de uma posição profundamente desequilibrada no tocante ao domínio sobre a informação ${ }^{40}$.

No mesmo sentido do que afirmou Ascensão, concorde-se com a ideia de Sampaio, que alegou:

A total transparência do indivíduo aos olhos do Estado e das empresas, detentoras de monopólio de informação, agudiza a concentração de poder, fragiliza o controle que deve ser exercido pela sociedade - e não, sobre a sociedade - e tende a aprofundar a desigualdade de suas relações, favorecendo as discriminações e o conformismo social e político $[\ldots]^{41}$.

Com o surgimento da tecnologia, o direito à privacidade se apresenta como uma nova forma de liberdade pessoal, que já não é mais a liberdade de recusar ou proibir a utilização de informações sobre a própria pessoa, mas se transformou na liberdade de exercer um direito ao controle sobre os dados que concernem à própria pessoa, que saíram da esfera da intimidade para se converter em elementos de um arquivo eletrônico público ou privado ${ }^{42}$. Segundo Sampaio, esta é a liberdade informática que consiste no direito de autotutela da própria identidade informática: o direito de controlar e de proteger os dados pessoais inscritos em um arquivo, em um banco de dados ou em um programa eletrônico ${ }^{43}$. Reconhece-se, afirma-se, declara-se o direito à privacidade; é preciso, também, concretizá-lo.

A proteção à intimidade e à vida privada é um valor democrático essencial que precisa ser concretizado. Com o avanço e o surgimento de novas tecnologias, 
é preciso regulamentar e controlar a utilização dos dados pessoais, tendo em vista que possuem conteúdo econômico e podem ser comercializados ${ }^{44}$, para salvaguardar os direitos fundamentais. Além disso, é preciso que haja o consentimento expresso da pessoa envolvida, antes da utilização de suas informações pessoais.

Sabe-se que utilizar o nome e a imagem das pessoas com fins comerciais e econômicos - para obter lucro na sociedade de consumo - sem remunerá-las por isso vai de encontro às normas e aos princípios que protegem os direitos de personalidade. Por isso, existe a necessidade real de se regulamentar a matéria, de maneira responsável, tendo em vista os princípios da proteção dos dados pessoais constantes da Constituição da República de 1988. Isto é, a Constituição dispôs sobre os princípios orientadores da proteção da privacidade, da vida privada, da liberdade de expressão, da proteção de dados. É preciso concretizar esses princípios constitucionais e regulamentá-los por meio de legislações infraconstitucionais.

Mendes cita a interdependência existente entre o tema da proteção dos dados pessoais e o tema da segurança da informação, em função do avanço tecnológico e da utilização de redes informatizadas. Afirma a autora:

[...] em um mundo em que os sistemas informáticos estão conectados em rede e são caracterizados pela sua ubiquidade, não há como garantir a proteção da privacidade e dos dados pessoais sem uma política adequada de segurança da informação e uma gestão de riscos de incidentes de informação ${ }^{45}$.

E continua: "a proteção da privacidade e a política de segurança da informação formam, portanto, duas faces da mesma moeda; a efetividade de uma depende da efetividade da outra" ${ }^{\prime 4}$.

Com base no disposto na Constituição, é possível verificar uma imposição de princípios básicos a que deve obedecer a utilização da informática, especialmente no tocante aos direitos fundamentais e à ordem constitucional do Estado Social e Democrático de Direito. Da mesma forma, é necessário examinar o panorama legislativo atual, para compreender em que medida o Estado atua na proteção da privacidade, dos dados e dos registros pessoais.

As leis de proteção de dados e de registros pessoais em vigor em outros países - e nas quais o legislador está se baseando para elaborar a lei brasileira consagram o regime de tutela das liberdades contra os perigos e as ameaças à privacidade dos chamados bancos de dados e do tratamento, informatizado ou não, do conteúdo desses bancos ${ }^{47}$. A regulamentação não se destina a todo e qualquer conteúdo, mas apenas àqueles que contenham informações de caráter pessoal ou nominativo.

Dados pessoais são aquelas informações que permitem identificar a pessoa a quem dizem respeito. A proteção dos dados pessoais tem como objeto (1) o direito à intimidade e (2) o direito à identidade pessoal. Enquanto o primeiro importa na autodeterminação informativa ${ }^{48}$, o segundo visa a impedir que a identidade pessoal seja alterada por informações inexatas ou incompletas. É preciso evoluir da autodeterminação informativa em favor do direito à proteção dos dados pessoais $^{49}$.

Atualmente, o direito fundamental à proteção de dados pessoais é um direito autônomo ${ }^{50}$. É importante ressaltar que não basta as leis enumerarem certos princípios e reconhecerem os direitos das pessoas cujos dados tenham sido ou venham a ser tratados. É necessário, para a efetiva tutela dos dados e dos registros pessoais, que os instrumentos garantidores do cumprimento desses princípios e desses direitos sejam igualmente determinados e regulamentados pela previsão de um regime de controle. Sampaio sugere que esse controle pode ser exercido pela própria unidade processadora dos dados, ou pela criação de órgãos de controle, ou pela participação e pela intervenção das pessoas afetadas ${ }^{51}$.

Mesmo que se entenda que cabe a cada um decidir a dimensão e a forma de penetração do raio ou âmbito moral no qual incide a privacidade, cuja invasão pelo público é remotamente permitida, e sempre de acordo com o critério da mínima invasão ${ }^{52}$, a proteção da privacidade deve ser regulamentada, para não haver arbitrariedades por parte do setor público nem do setor privado.

Isto porque, atualmente, a penetração da esfera privada do indivíduo, mediante conhecimento e divulgação de seus dados pessoais por terceiros, está bem além do patamar do ordinário e cotidiano aborrecimento. $\mathrm{O}$ envio de correspondências (inclusive e-mails e mensagens de celular, conhecidos como sms) endereçadas ao indivíduo por quem não contratou com ele revela absoluta vulneração de seus dados pessoais mais elementares e mais restritos para a adequada segurança pessoal. O efetivo dano à esfera privada se nota pelo irrecuperável controle dos dados privados do indivíduo. Segundo os princípios que orientam a matéria, é ilícita a conduta de quem transfere, sem aquiescência do titular, seus dados privados. Ademais, a divulgação desautorizada de dados sensíveis ${ }^{53}$ da pessoa fere direito personalíssimo, ao mesmo tempo 
que acentua a vulnerabilidade da dignidade da pessoa humana.

A facilidade de comunicação e de intercâmbio de informações pessoais ocasionada pelo avanço da tecnologia aumenta o risco potencial da utilização abusiva dessas informações, e acentua a vulnerabilidade do direito à privacidade. Assim, é necessário que o ordenamento jurídico ofereça "instrumentos que assegurem que a fruição das novas vantagens proporcionadas pela tecnologia possa ocorrer de forma proporcional à manutenção das expectativas de privacidade $[\ldots]^{\prime \prime 54}$.

O Estado não está alheio à necessidade de resguardar o direito fundamental à proteção de dados e de registros pessoais. Por isso, é preciso examinar o CDC, em conjunto com o PLS no 281/201255, que altera o CDC para dispor sobre o comércio eletrônico.

Da mesma forma que o PLS 281/2012 atualiza o CDC para dispor sobre o comércio eletrônico e, ao proceder nesse sentido, regulamenta o direito fundamental à proteção de dados e de registros pessoais, principalmente nos meios de comunicação a distância e eletrônicos (bancos de dados informatizados), a entrada em vigor da Lei $n^{-}$12.965/2014, que regulamenta o uso da internet no Brasil, significa um avanço no reconhecimento da necessidade de proteção dos dados e dos registros pessoais. Embora não seja uma lei específica sobre o tema, prevê uma série de dispositivos sobre a proteção de dados. $\mathrm{O}$ exame desse diploma legal será feito à luz do princípio da proteção de dados e de registros pessoais. Além disso, é feita uma breve análise do Anteprojeto de Lei de Proteção de Dados Pessoais ${ }^{56}$ e de outras legislações infraconstitucionais que tratam do tema dos bancos de dados.

\subsection{A proteção dos dados e dos registros pessoais como um direito do consumidor}

O Código de Defesa do Consumidor é lei de ordem pública e de interesse social e foi elaborada por determinação constitucional, de acordo com o mandamento expresso contido no art. 48 do Ato das Disposições Constitucionais Transitórias (ADCT) ${ }^{57}$. Ademais, o direito do consumidor está incluído no rol dos direitos fundamentais, art. 5ㅇ, XXXII, da Constituição da República de $1988^{58}$, portanto, numa hierarquia de cláusula pétrea ${ }^{59}$.

O CDC dispõe sobre os bancos de dados e cadastros de consumidores no art. $43^{60}$, ao determinar que o consumidor "terá acesso às informações existentes em cadastros, fichas, registros e dados pessoais e de consumo arquivados sobre ele, bem como sobre as suas respectivas fontes".
Com relação à aplicação do art. 43 do $\mathrm{CDC}$, Mendes, assim como Doneda, destacam que o acórdão proferido no RESp 22.337-RS ${ }^{61}$, de relatoria do Ministro Ruy Rosado de Aguiar Júnior, estabeleceu um novo conceito de privacidade, ao interpretar e aplicar o art. 43 do CDC aos cadastros de informações em bancos de dados ${ }^{62}$.

Constou do voto do Ministro Ruy Rosado lição magistral e bastante atual:

A inserção de dados pessoais do cidadão em bancos de informações tem se constituído em uma das preocupações do Estado moderno, onde o uso da informática e a possibilidade de controle unificado das diversas atividades da pessoa, nas múltiplas situações de vida, permite o conhecimento de sua conduta pública e privada, até nos mínimos detalhes, podendo chegar à devassa de atos pessoais, invadindo área que deveria ficar restrita à sua intimidade; ao mesmo tempo, o cidadão objeto dessa indiscriminada colheita de informações, muitas vezes, sequer sabe da existência de tal atividade, ou não dispõe de eficazes meios para conhecer o seu resultado, retificá-lo ou cancelá-lo. [...] A importância do tema cresce de ponto quando se observa o número imenso de atos da vida humana praticados através da mídia eletrônica ou registrados nos disquetes de computador. [...] Na Alemanha, por exemplo, a questão está posta no nível das garantias fundamentais, com o direito de autodeterminação informacional (o cidadão tem o direito de saber quem sabe o que sobre ele), [...]. No Brasil, a regra do art. 5º, inc. X, da Constituição de 1988, é um avanço significativo $[\ldots]^{63}$.

Depois dessa importante decisão, muitos autores se dedicaram ao estudo dos bancos de dados e cadastro de consumidores e os bancos de dados de proteção ao crédito, como, por exemplo, Bessa ${ }^{64}$ e Efing ${ }^{65}$, entre outros $^{66}$.

Doneda assevera:

Uma fundamentação bastante robusta tanto para propugnar por uma maior efetividade do habeas data quanto para a tutela dos dados pessoais através de outros instrumentos disponíveis em nosso ordenamento, como, por exemplo, o art. 43 do Código de Defesa do Consumidor em todo o seu amplo leque principiológico, poderia ser a consolidação do entendimento segundo o qual a proteção de dados é um direito fundamental, cuja fundamentação se encontra basicamente nos incisos X e XII do art. $5^{\circ}$ da Constituição Federal, relativos às garantias da vida privada, intimidade $\mathrm{e}$ comunicação de dados ${ }^{67}$. 
Assim como o art. 43, o art. 39, III, do $\mathrm{CDC}^{68}$ é uma iniciativa legal de proteção à reserva pessoal, cuja observância não se nota pela conduta invasiva de quem permite o tráfego de dados que não lhe pertencem, cujo sigilo é imanente, porque se cuida de direito personalíssimo. Esse dispositivo determina que seja prática abusiva o envio não solicitado de produtos e serviços. Ao enviar a publicidade não solicitada para o e-mail ou o telefone celular do consumidor, o fornecedor está realizando uma prática abusiva, apesar de corriqueira. Nesse sentido, a opinião de Jabur:

O envio de correspondências a quem não lhe forneceu o logradouro, nem, portanto, the deu a conhecer o seu domicílio vulnera o direito ao recato, ao isolamento. E nada importa o conteúdo da missiva, mas sua finalidade privada, comercial ou não. Idêntica e antecedente violação se revelou através da transmissão dos dados sensíveis a pessoas naturais ou jurídicas com as quais seu titular não mantém a mínima relação sociojurídica ${ }^{69}$.

O CDC é aplicável à proteção de informações pessoais dos consumidores ${ }^{70}$, pois os arquivos de consumo, dos quais são espécie os bancos de dados e os cadastros de fornecedores ${ }^{71}$, estão sujeitos às disposições do art. 43 do $\mathrm{CDC}$, inclusive nas relações estabelecidas pela internet.

Atualmente, discute-se a atualização do CDC, para tratar do comércio eletrônico, por meio do PLS no $281 / 2012$, ainda em tramitação ${ }^{72}$. No que toca à segurança, à privacidade e à proteção de dados na sociedade de consumo $^{73}$, o PLS no 281/2012 cria novos direitos básicos do consumidor, ao propor o acréscimo dos incisos XI e XII ao art. $6^{\circ}$ do CDC, com a seguinte redação:

Art. 6⿳⺈ São direitos básicos do consumidor:

$[\ldots]$ :

XI - a privacidade e a segurança das informações e dados pessoais prestados ou coletados, por qualquer meio, inclusive o eletrônico, assim como o acesso gratuito ao consumidor a estes e suas fontes;

XII - a liberdade de escolha, em especial frente a novas tecnologias e redes de dados, sendo vedada qualquer forma de discriminação e assédio ao consumo;

$[\ldots]^{74}$.

É importante ressaltar que o CDC é uma lei protetiva dos direitos dos consumidores. Logo, a liberdade de escolha e de expressão que estarão sendo resguardadas nas relações de consumo, inclusive as celebradas no meio eletrônico, serão as do consumidor, sempre que este se relacionar com fornecedores de produtos e serviços.

Ressalte-se que esses incisos XI e XII do art. 6으, sugeridos pelo PLS no ${ }^{\circ} 81 / 2012$, se forem aprovados, deverão ser aplicados no âmbito das relações reguladas pela Lei no $12.965 / 2014$, que estabelece princípios, garantias, direitos e deveres para o uso da internet no Brasil, bem como a toda e qualquer relação de consumo, não só às realizadas em meio eletrônico. Entende-se, portanto, que a Lei $\mathrm{n}^{\mathrm{o}} 12.965 / 2014$, ao regulamentar o uso da internet no Brasil, assegura liberdade de escolha e de expressão do consumidor, parte vulnerável da relação de consumo celebrada no meio virtual, em vista da aplicação em diálogo dessa norma com o CDC.

Nesses dois novos incisos do art. 6º do CDC, "há um robustecimento na proteção do consumidor" 75 , com base na confiança, almejando todos os fenômenos de distribuição a distância. Os incisos XI e XII do art. $6^{0}$ foram pensados pela Comissão de Juristas do Senado Federal para a Atualização do Código de Defesa do Consumidor ${ }^{76}$, que almejou a equiparação das compras feitas fora do estabelecimento comercial, em domicílio e a distância para dar mais segurança às relações ${ }^{77}$. Assim, serão equiparadas as compras feitas pelo site estando ou não o consumidor no estabelecimento do fornecedor. Tome-se o exemplo do consumidor que adquire o seu ingresso de cinema em um terminal automatizado no saguão do estabelecimento, porque a fila de atendimento convencional está muito comprida ${ }^{78}$.

A alteração principal almejada pelo PLS $\mathrm{n}^{\mathrm{o}}$ 281/2012 sobre comércio eletrônico ao CDC começa, realmente, do acréscimo do art. 44-A ao CDC. O art. 44-A do Projeto de Lei inaugura a Seção VII do Capítulo V (Das Práticas Comerciais) do Título I (Dos Direitos do Consumidor) até então inexistente, com o título de "Do Comércio Eletrônico", para tratar dessa novel questão.

Nos termos do art. 44-A, a Seção VII:

dispõe sobre normas gerais de proteção do consumidor no comércio eletrônico e a distância, visando fortalecer a sua confiança e assegurar tutela efetiva, com a diminuição da assimetria de informações, a preservação da segurança nas transações, a proteção da autodeterminação e da privacidade dos dados pessoais ${ }^{79}$.

$\mathrm{O}$ art. 44-A dispõe sobre confiança, liberdade do outro, da parte mais fraca, vulnerável, e menciona a boa-fé. É uma norma de abertura, tem como objetivo "fortalecer a confiança e assegurar a tutela efetiva do consumidor, com a diminuição da assimetria de 
informações, a preservação da segurança nas transações, a proteção da autodeterminação e da privacidade dos dados pessoais"80. O dispositivo prevê a aplicação das normas do CDC aos contratos celebrados a distância, ao meio eletrônico ou similar, antevendo o avanço tecnológico, o que é positivo.

O art. 44-D, VII, do PLS 281/2012, na forma do substitutivo, dispõe sobre o dever de informar às autoridades competentes e ao consumidor sobre o vazamento de dados ou o comprometimento da integridade, mesmo que parcial, da segurança do sistema. Esse dispositivo espelha a preocupação do legislador de proteger o consumidor em sua segurança e a proteção da integridade das informações do consumidor.

A redação final do art. 44-F do PLS 281/2012, na forma de seu substitutivo, não respeitou a proposição constante de Anteprojeto elaborado pela Comissão de Juristas do Senado Federal para a atualização do CDC na parte referente ao comércio eletrônico. Durante a tramitação do PLS 281/2012, houve a inclusão de algumas disposições que podem prejudicar o consumidor. É o caso do $\S 6^{\circ}$ do art. 44-F, que desconsiderou a consagrada previsão legal da responsabilidade solidária entre todos os participantes da cadeia de fornecimento de produtos e serviços presente no CDC em vários dispositivos, tais como nos arts. $12,14,18$ e $20^{81}$.

Desse modo, o art. 44-F, $\S 6^{\circ}$, do PLS 281/2012, na forma de seu substitutivo, se for aprovado assim como está redigido, criará uma exceção à regra da responsabilidade civil solidária dos fornecedores para os conglomerados econômicos (dessa forma, segundo a previsão atual do PLS 281/2012, não haverá responsabilidade civil solidária entre as empresas que formam um conglomerado econômico), diversamente do que vem decidindo o STJ: "[...] Se empresa brasileira aufere diversos benefícios quando se apresenta ao mercado de forma tão semelhante a sua controladora americana, deve também, responder pelos riscos de tal conduta" $"$.

Note-se que o legislador desconsiderou que, muitas vezes, o consumidor não possui a informação sobre quais empresas integram um determinado grupo econômico e se integram um. Assim, é difícil ter ciência de, no momento da contratação, qual grupo econômico determinado fornecedor pertence, a não ser que seja prevista a obrigação do fornecedor de informar clara e inequivocamente ao consumidor que pertence a determinado grupo econômico integrado pelas empresas "A", "B", "C", "D", etc. Somente dessa forma o consumidor terá a oportunidade de recusar o recebimento de mensagens indesejadas tanto da empresa com a qual está contratando, como das demais empresas do grupo. Além disso, a regra permite que todas as empresas do conglomerado econômico enviem mensagens não solicitadas ao consumidor, menos aquela com quem o consumidor contratou e manifestou a vontade de não receber mensagens. Por isso, não agiu bem o legislador ao redigir a norma do art. 44-F, $\S 6^{\circ}$, do PLS 281/2012, na forma de seu substitutivo. Entendese que, se entrar em vigor, significará um retrocesso aos direitos e às garantias do consumidor ${ }^{83}$.

O mesmo ocorre com o disposto no $\S 7^{\circ}$ do art. 44-F do PLS 281/2012, na forma de seu substitutivo. Esse parágrafo prevê a permissão aos fornecedores que integram um conglomerado econômico veicular, exibir, licenciar, alienar, compartilhar, doar ou, de qualquer forma, ceder ou transferir dados, informações ou identificadores pessoais, sem expressa autorização e consentimento informado do seu titular. Ou seja, a regra permite que o fornecedor que contrata com o consumidor transmita aos demais integrantes do conglomerado econômico - desde que não seja aquela empresa fornecedora que está diretamente contratando com o consumidor - possam fazer tudo aquilo que o fornecedor contratante é proibido de fazer ${ }^{84}$.

O art. 44-F, §7으, do PLS 281/2012, na forma de seu substitutivo, vai de encontro à ideia de proteção de dados e de registros pessoais prevista na Constituição, no Código de Defesa do Consumidor e no Anteprojeto de Lei de Proteção de Dados Pessoais que prevê, em seu art. 11, V, o seguinte: “Art. 11. No momento da coleta dos dados pessoais, o titular será informado de forma clara e explícita sobre: [...]; V - os sujeitos para os quais os dados podem ser comunicados e o seu âmbito de difusão; [...]"85.

Durante a tramitação do PLS 281/2012, houve a inclusão do art. 44-G ao texto elaborado pela Comissão de Juristas do Senado Federal para a atualização do CDC na parte referente ao comércio eletrônico. Esse dispositivo prevê o seguinte:

Art. 44-G. Na oferta de produto ou serviço por meio da rede mundial de computadores (internet) ou qualquer modalidade de comércio eletrônico, somente será exigida do consumidor, para a aquisição do produto ou serviço ofertado, a prestação das informações indispensáveis à conclusão do contrato.

Parágrafo Único. Quaisquer outras informações, além das indispensáveis, terão caráter facultativo, devendo o consumidor ser previamente avisado dessa condição ${ }^{86}$.

Esse dispositivo é uma tentativa - espera-se que eficaz - de proteção das informações sensíveis 
dos consumidores, entendidas estas como as que podem possibilitar a discriminação dos seus titulares, conforme se mencionou acima ${ }^{87}$. Isto porque só é permitido ao fornecedor exigir do consumidor apenas as informações indispensáveis à conclusão do contrato.

Também, o PLS 281/2012, na forma de seu substitutivo, cria um tipo penal e administrativo, ao propor a inclusão do art. 72-A no $\mathrm{CDC}$, que prevê a proibição de veiculação, exibição, licenciamento, alienação, compartilhamento, doação, cessão ou transferência de dados, de informações ou de identificadores pessoais ${ }^{88}$, sem a expressa autorização de seu titular e consentimento informado, impondo a pena de detenção. Esse dispositivo está de acordo com a ideia de proteção de dados e de registros pessoais. Entretanto o mesmo dispositivo não considera crime o fato de um fornecedor veicular, exibir, licenciar, alienar, compartilhar, doar ou, de qualquer forma, ceder ou transmitir dados, informações ou identificadores pessoais, sem a expressa autorização de seu titular e consentimento informado, entre fornecedores que integrem um mesmo conglomerado econômico. Nesse ponto, andou mal o legislador, ao permitir que o intercâmbio desautorizado de dados e de registros pessoais dos consumidores seja realizado entre os fornecedores de um mesmo grupo econômico.

Em matéria de novas tecnologias, a proposta de PLS n⿳0 281/2012 “objetiva reforçar as linhas de informação do CDC e adaptá-las às novas necessidades, sem descuidar da proteção dos dados e da privacidade do consumidor" $" 89$.

Ao tempo em que se debate a atualização do CDC, entrou em vigor, em 15 de maio de 2013, o Decreto no 7.962 , de 15 de março de 2013, que regulamenta o Código de Defesa do Consumidor para dispor sobre a contratação no comércio eletrônico. $\mathrm{O}$ art. $4^{\circ}$ desse diploma dispõe sobre a segurança na transmissão dos dados dos consumidores, ao determinar que: "Art. 4을 Para garantir o atendimento facilitado ao consumidor no comércio eletrônico, o fornecedor deverá:[...];VII - utilizar mecanismos de segurança eficazes para pagamento e para tratamento de dados do consumidor; [...]"90. É necessário aplicar esse dispositivo em conjunto com o CDC e a Lei no $12.965 / 2014$.

Despois de examinada a proteção dos dados e dos registros pessoais no ordenamento jurídico brasileiro como um direito fundamental, previsto na Constituição, e como um direito do consumidor, de acordo com o Código de Defesa do Consumidor, é preciso verificar como a proteção dos dados e dos registros pessoais será realizada nas relações estabelecidas pela internet, regulamentada pela Lei no $12.965 / 2014$. Também, analisa-se o Anteprojeto de Lei de Proteção de Dados
Pessoais, tendo em vista a necessidade de regulamentar a matéria em uma lei específica como uma forma de resguardar os direitos fundamentais à dignidade da pessoa humana, à vida privada, à privacidade, à liberdade da pessoa e à proteção de dados e de registros pessoais.

\section{A REGULAMENTAÇÃO DO USO DA INTERNET NO BRASIL E O DIREITO À PROTEÇÃO DOS DADOS E DOS REGISTROS PESSOAIS}

A regulamentação do uso da internet no Brasil e a proteção dos direitos dos consumidores estão sendo muito debatidas no cenário nacional. Por isso, é necessário analisar a Lei no 12.965 , de 23 de abril de 2014, que estabelece princípios, garantias, direitos e deveres para o uso da internet no Brasil. Com a entrada em vigor desse diploma legal, conhecido como o "marco civil da internet", em 23 de junho de 2014, os aplicadores do Direito deverão ter o cuidado de não retroceder nos direitos e garantias alcançados pelo ordenamento jurídico brasileiro ao aplicar essa legislação. Por isso, sugere-se uma aplicação conjunta, um "diálogo das fontes" ${ }^{11}$ entre o Código de Defesa do Consumidor e a Lei 12.965/2014, à luz do princípio da dignidade da pessoa humana, assegurado pela Constituição, e baseada no princípio da proibição do retrocesso dos direitos fundamentais. Do mesmo modo, é preciso tecer alguns comentários acerca do Anteprojeto de Lei de Proteção de Dados Pessoais que ainda está sendo discutido.

\subsection{A Lei no 12.965/2014 - o marco civil da internet no Brasil}

No que toca ao direito à proteção de dados pessoais, em conjunto com o disposto no CDC, deve-se aplicar a Lei do Cadastro Positivo (Lei no 12.414/2011), que dispôs sobre a formação e a consulta a bancos de dados com informações de adimplemento, para a formação do histórico de crédito $^{92}$, e a Lei $\mathrm{n}^{\mathrm{0}}$ 12.965/2014, que regulamenta o uso da internet. A Lei do Cadastro Positivo ampliou a possibilidade do fluxo de dados no mercado, possibilitou a formação de bancos de dados com informações de adimplemento, buscou estabelecer regras de proteção à privacidade e métodos de controle e fiscalização dessa atividade. Assim, no caso de bancos de dados virtuais e informatizados, aplica-se a Lei $\mathrm{n}^{\mathrm{o}}$ 12.414/2011 em conjunto com a Lei no 12.965/2014.

A aplicação em diálogo dessas normas deve ter por objetivo assegurar os direitos e as garantias dos consumidores e evitar o retrocesso daquilo que já foi conquistado na ordem jurídica nacional. Sendo 
assim, a aplicação da Lei no 12.965/2014 deve respeitar os direitos e as garantias dos consumidores assegurados pela Constituição, pelo Código de Defesa do Consumidor, pela Lei do Acesso à Informação (Lei no $12.527 / 2011$ ) e pela Lei do Cadastro Positivo.

A regulamentação do uso da rede mundial de computadores no Brasil, estabelecida pela Lei $\mathrm{n}^{-}$ $12.965 / 2014$, é originária de discussão no Congresso Nacional, por meio do Projeto de Lei da Câmara no 21 , de 2014 ( $\mathrm{n}^{\mathrm{o}}$ 2.126/2011, na Casa de origem), conhecido como marco civil da internet ${ }^{93}$. O texto da lei estabelece princípios, garantias, direitos e deveres dos usuários da rede ${ }^{94}$ e sofreu forte evolução, na tramitação, de um texto tendencioso, que servia claramente aos interesses de um determinado setor da sociedade, para um texto que valoriza a liberdade de acesso à rede e, na maioria das vezes, a defesa do consumidor ${ }^{95}$.

Em 23 de junho de 2014, entrou em vigor a Lei $\mathrm{n}$ ㅇ 12.965, de 23 de abril de $2014^{96}$. Esse diploma legal, conhecido como o "marco civil da internet", estabelece princípios, garantias, direitos e deveres para o uso da internet no Brasil (art. $\left.1^{\mathrm{O}}\right)^{97}$ e esclarece ser um de seus fundamentos a defesa do consumidor, em seu art. $2^{\circ}, \mathrm{V}$. Da mesma forma, o art. 3ํㅡㄹ parágrafo único, e o art. $6^{\text {o }}$ da Lei no 12.965/2014 garantem a aplicação do CDC à luz dos princípios constitucionais da dignidade da pessoa humana, da proteção da vida privada, da privacidade e dos dados pessoais, e a promoção do desenvolvimento humano, econômico, social e cultural no âmbito da internet.

Considera-se importante a entrada em vigor dessa legislação para a definição dos direitos e dos deveres dos internautas, usuários da rede mundial de computadores, sejam eles consumidores ou não. É preciso interpretar a lei de acordo com os mandamentos e valores constitucionais vigentes de proteção e defesa do consumidor no tocante aos princípios da dignidade da pessoa humana, da igualdade, da privacidade, da liberdade de expressão, da autodeterminação informativa, da proteção de dados e de registros pessoais, entre outros.

$\mathrm{O}$ art. $2^{\mathrm{o} 98}$ da lei determina os fundamentos para o uso da internet no Brasil. São eles: a liberdade de expressão (caput); o reconhecimento da escala mundial da rede (inc. I); os direitos humanos, o desenvolvimento da personalidade e o exercício da cidadania em meios digitais (inc. II); a pluralidade e a diversidade (inc. III); a abertura e a colaboração (inc. IV); a livre-iniciativa, a livre-concorrência e a defesa do consumidor (inc. V); e a finalidade social da rede (inc. VI).

Note-se que a defesa do consumidor é um dos fundamentos da disciplina do uso da internet no Brasil, em conjunto com a livre-iniciativa e a livre-concorrência, assim como manda a Constituição, art. 170, V. Por isso, sustenta-se que a Lei $\mathrm{n}^{\mathrm{o}} 12.965 / 2014$ deve ser aplicada de acordo com o princípio da vulnerabilidade do consumidor e as normas do ordenamento que disponham sobre a proteção do consumidor, como o CDC, a Lei do Cadastro Positivo e a futura lei sobre a proteção dos dados e dos registros pessoais, quando for aprovada.

Com relação à atual redação do $\operatorname{art.~}^{2}$ da Lei $\mathrm{n}$ 오 12.965/2014, é preciso questionar se existe censura no Brasil a ponto de o legislador fazer prevalecer o princípio da liberdade de expressão (caput do art. $2^{\circ}$, da Lei $\mathrm{n}^{\mathrm{O}}$ 12.965/2014) em detrimento da dignidade da pessoa humana (art. 1으, III, da Constituição), ou se a lei, nesse aspecto, significa uma afronta direta ao texto constitucional, já que a liberdade de expressão deve respeitar os direitos da personalidade e a dignidade de pessoa humana.

O art. $3^{\circ}$ da Lei $n^{\circ} 12.965 / 2014^{99}$ determina os princípios que devem pautar a disciplina do uso da internet no Brasil. São eles: a liberdade de expressão, a comunicação e a manifestação de pensamento, nos termos da Constituição (inc. I); a proteção da privacidade (inc. II); a proteção dos dados pessoais, na forma da lei (inc. III - lei a ser aprovada, ainda em discussão, na forma do Anteprojeto de Lei de Proteção de Dados Pessoais ${ }^{100}$ ); a preservação e a garantia da neutralidade da rede (inc. IV); a preservação da estabilidade, da segurança e da funcionalidade da rede, por meio de medidas técnicas compatíveis com os padrões internacionais e pelo estímulo ao uso de boas práticas (inc. V); a responsabilização dos agentes de acordo com suas atividades, nos termos da lei (inc. VI); a preservação da natureza participativa da rede (inc. VII); a liberdade dos modelos de negócios promovidos na internet, desde que não conflitem com os demais princípios estabelecidos na lei (inc. VIII).

Em resumo, o art. 3을 destaca os princípios para a utilização da internet, fazendo referência à proteção da privacidade e à proteção dos dados pessoais. Nesse sentido, pode-se afirmar que houve um amadurecimento do ordenamento jurídico brasileiro no sentido de reconhecer que a proteção de dados pessoais não se circunscreve ao direito à privacidade, nem é somente uma concretização desse direito ${ }^{101}$. Segundo Doneda, são dois direitos fundamentais distintos: (1) o direito à privacidade; e (2) o direito à proteção de dados. $\mathrm{O}$ autor explica que "a privacidade tem um caráter mais subjetivo que muitas vezes impede uma resposta clara, harmônica e rápida aos problemas"102. A proteção de dados pessoais tem, em seu campo de aplicação, um caráter mais objetivo, visando a proteger o dado em si e, por meio dele, a pessoa ${ }^{103}$. 
De acordo com a Lei n⿳0 12.965/2014, “a proteção de dados pessoais deve se dar nos termos da lei" (art. $2^{\underline{o}}$, III). Ou seja, o texto menciona a existência de uma legislação geral de proteção de dados pessoais, não apenas na internet ${ }^{104}$. Trata-se do Anteprojeto de Lei de Proteção de Dados Pessoais ${ }^{105}$, ainda em discussão no Ministério do Planejamento, de onde seguirá para análise da Casa Civil, último estágio antes de se tornar um projeto de lei ${ }^{106}$.

O parágrafo único do art. $3^{\circ}$ da Lei $n^{\circ}$ 12.965/2014 determina que os princípios expressos nessa lei não excluem outros previstos no ordenamento jurídico brasileiro relacionados à matéria ou nos tratados internacionais em que a República Federativa do Brasil seja parte. Trata-se de uma norma de abertura, que será fundamental para o seu diálogo com as normas de proteção e defesa do consumidor, já que a lei que regulamenta o uso da internet no Brasil traz a figura do usuário e não a do consumidor, que é o verdadeiro usuário dos produtos e serviços de internet. Deve-se aplicar e interpretar a lei considerando-se os princípios da liberdade de expressão, da privacidade e da neutralidade à luz do princípio da vulnerabilidade da parte mais fraca que, na relação de consumo, é o consumidor.

Isto é, os princípios que disciplinam o uso da internet no Brasil não mencionam nenhum princípio específico de proteção ao direito do consumidor (a não ser o da "responsabilização dos agentes de acordo com suas atividades, nos termos da lei"), porém o art. $3^{\circ}$, em seu parágrafo único, assegura a abertura do regulamento do uso da internet no Brasil às outras leis existentes. Em outras palavras, a Lei no $12.965 / 2014$ assegura o diálogo das fontes ${ }^{107}$. Daí se retira a ideia de que os direitos dos consumidores hoje assegurados pelo CDC e na legislação especial e geral se somarão aos "novos" direitos assegurados pela Lei no $12.965 / 2014^{108}$.

$\mathrm{O}$ art. $3^{\circ}$ da lei que regulamenta o uso da internet no Brasil vai ao encontro da ideia de proteção prevista no PLS 281/2012, ao prever a "garantia da liberdade de expressão, comunicação e manifestação de pensamento, nos termos da Constituição Federal" (art. 3ํㅡ, I, da Lei no 12.965/2014); a proteção da privacidade e de dados pessoais, na forma da lei (art. 3ㅜㅡ, II e III, da Lei $\mathrm{n}^{\mathrm{o}}$ 12.965/2014), sendo que o parágrafo único, do art. 3 , como referido acima, faz menção expressa de que “os princípios expressos nesta lei não excluem outros previstos no ordenamento jurídico pátrio relacionados à matéria ou nos tratados internacionais em que a República Federativa do Brasil seja parte", realizando um verdadeiro "diálogo das fontes" com o Código de Defesa do Consumidor e a Constituição da República de 1988.
$\mathrm{O}$ art. 4 ${ }^{\mathrm{O}}$ da Lei $\mathrm{n}^{\mathrm{O}} 12.965 / 2014$ determina os objetivos da regulamentação da internet no Brasil. São eles: a promoção do direito de acesso à internet (inc. I); a promoção do acesso à informação, ao conhecimento e à participação na vida cultural e na condução dos assuntos públicos (inc. II); a promoção da inovação e do fomento à ampla difusão de novas tecnologias e modelos de uso e acesso (inc. III); e a promoção da adesão a padrões tecnológicos abertos que permitam a comunicação, a acessibilidade e a interoperabilidade entre aplicações e bases de dados (inc. IV) ${ }^{109}$.

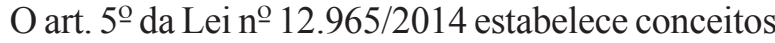
básicos para os efeitos da lei, tais como a definição de internet (inc. I); de terminal (inc. II); de endereço de protocolo de internet (inc. III); de administrador de sistema autônomo (inc. IV); de conexão à internet (inc. V); de registro de conexão (inc. VI); de aplicações de internet (inc. VII); de registros de acesso a aplicações de internet (inc. VIII) ${ }^{110}$.

$\mathrm{O}$ art. $6^{\circ}$ da Lei $\mathrm{n}^{\mathrm{o}} 12.965 / 2014$ dispõe sobre uma importante regra de hermenêutica, que deve ser considerada na aplicação e na interpretação de seus dispositivos, ao determinar que:

$\mathrm{Na}$ interpretação desta Lei serão levados em conta, além dos fundamentos, princípios e objetivos previstos, a natureza da internet, seus usos e costumes particulares e sua importância para a promoção do desenvolvimento humano, econômico, social e cultural ${ }^{111}$.

É importante para o desenvolvimento da internet a proteção dos direitos dos consumidores. $\mathrm{O}$ art. $6^{\circ}$ da Lei $\mathrm{n}^{\mathrm{o}}$ 12.965/2014 terá papel fundamental para garantir o não retrocesso da proteção dos direitos dos consumidores na promoção do desenvolvimento gerado pela internet nos âmbitos humano, econômico, social e cultural.

$\mathrm{O}$ art. $7^{\circ}$ da Lei $\mathrm{n}^{\mathrm{o}}$ 12.965/2014 inaugura o capítulo 2, que trata dos direitos e das garantias dos usuários. Entre os direitos e as garantias dos usuários, alguns desses usuários são caracterizados como consumidores (ex vi arts. $2^{\circ}, 29$ e 17 do CDC) no seu acesso à internet. Por isso, é preciso interpretar e aplicar a lei à luz dos princípios de proteção do consumidor.

$\mathrm{O}$ art. $7^{\circ}$ da lei menciona a garantia a direitos já assegurados pelo CDC, tais como o direito a ter acesso a informações claras e completas constantes dos contratos de prestação de serviços. A novidade trazida pela lei é a previsão expressa sobre o regime de proteção aos seus dados pessoais, aos registros de conexão e aos registros de acesso a aplicações de internet, bem como sobre práticas de gerenciamento da rede que possam 
afetar a qualidade dos serviços oferecidos (art. 7으, IV,

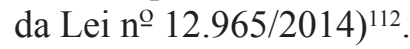

No mesmo sentido de aprofundamento e reforço da proteção e do direito do consumidor no Brasil, a redação do art. $4^{\circ}$, II, e do art. $7^{\circ}$, VI, VIII, XI e XIII, da Lei no $12.965 / 2014$, corroboram com o objetivo de proteção do usuário e do consumidor com relação a seu direito fundamental a informações claras e completas.

$\mathrm{O}$ art. $7^{\circ}$ da Lei $\mathrm{n}^{\mathrm{O}} 12.965 / 2014$ passa a tratar mais claramente dos direitos dos usuários, determinando que, no acesso à internet, são assegurados os direitos de: inviolabilidade da intimidade e da vida privada, bem como a sua proteção e indenização pelo dano material ou moral decorrente de sua violação (inc. I); inviolabilidade e sigilo da transmissão das comunicações pela internet (inc. II); inviolabilidade e sigilo das comunicações privadas armazenadas (inc. III); não suspensão da conexão à internet, a não ser que haja débito decorrente de sua utilização (inc. IV); manutenção da qualidade contratada de conexão à internet (inc. V); entre outros.

$\mathrm{O}$ inc. VI do art. $7^{\mathrm{O}}$ da Lei $\mathrm{n}^{\mathrm{O}} 12.965 / 2014$ assegura ao usuário-consumidor o direito a informações claras e completas constantes dos contratos de prestação de serviços, com detalhamento sobre o regime de proteção aos registros de conexão e aos registros de acesso a aplicações de internet, bem como sobre práticas de gerenciamento de rede que possam afetar a sua qualidade. Esse dispositivo favorecerá a proteção da privacidade e a proteção dos dados e dos registros pessoais do usuário, se for eficaz, e será aplicado em conjunto com o art. 43 do CDC.

Outra previsão legal importante para a proteção de dados e de registros pessoais é a constante do inc. VII do art. $7^{\text {o }}$ da Lei $n^{\circ} 12.965 / 2014$, que determina ser direito do usuário o não fornecimento a terceiros de seus dados pessoais, inclusive registros de conexão e de acesso a aplicações de internet, a não ser que haja consentimento livre, expresso e informado do usuário, ou nas hipóteses previstas em lei. Ou seja, a utilização dos dados pessoais do consumidor (inclusive o histórico de navegação na internet), "só poderá ocorrer se os internautas manifestarem consentimento livre, expresso e informado, o qual poderá ser revogado a qualquer momento pelo próprio usuário, que tem direito à exclusão definitiva de todos os dados pessoais que tiver fornecido pelo site" 113 .

Oliveira é categórico:

Conclui-se daí que os provedores de aplicações (ou seja, os sites) deverão facultar ao internauta, de modo claro, compreensível e sem emboscadas que induzam a resposta, o direito de consentir ou não com a transferência a terceiros de seus dados pessoais (e aí se inclui o seu histórico de navegação, ou seja, os seus registros de acesso a aplicações).

Deverá, ainda, o provedor de aplicações disponibilizar ao internauta o acesso a canal de comunicação que lhe permita, com facilidade, clareza e sem emboscadas que induzam a resposta, a revogação do consentimento externado anteriormente pelo usuário ${ }^{114}$.

Note-se que há uma antinomia entre o art. $7^{\circ}$, VII, da Lei $n^{\mathrm{o}} 12.965 / 2014$, e o art. 44-F, $\S \S 6^{\circ}$ e $7^{\circ}$ do PLS 281/2012. O art. 7ํㅡ, VII, da lei que regulamenta a internet no Brasil é mais favorável à proteção dos dados e dos registros pessoais do que as alterações sugeridas, nesse ponto, ao CDC.

O inc. VIII do art. $7^{\circ}$ da Lei $n^{\circ}$ 12.965/2014 determina que é direito do usuário ter informações claras e completas sobre a coleta, o uso, o armazenamento, o tratamento e a proteção de seus dados pessoais, que somente poderão ser utilizados para finalidades que (a) justifiquem sua coleta; (b) sejam lícitas; e (c) estejam previstas em contrato ${ }^{115}$. O dispositivo determina expressamente o cumprimento do princípio da finalidade da coleta de dados pessoais por parte dos fornecedores. A coleta e o tratamento de dados pessoais só são justificáveis para as atividades declaradas. Se uma empresa coleta e processa dados e informações para fornecer um serviço melhor para o consumidor, essa empresa não pode utilizar os mesmos dados para outra finalidade. "Isso seria um uso secundário dos dados que, na prática, faria o cidadão perder o controle sobre sua informação", afirma Doneda ${ }^{116}$, e completa: "o dado não pode ser um bem livremente apropriado por quem, por algum motivo, passa a ter acesso a ele" 117 .

O consentimento ao tratamento dos dados e dos registros pessoais é uma das modalidades de legitimação do tratamento de dados, que é possível e até desejado pelo cidadão, em muitas hipóteses, ou sempre que haja o interesse público. O art. 7º, IX, da Lei no 12.965/2014 determina que é direito do usuário o consentimento expresso sobre a coleta, o uso, o armazenamento e o tratamento de dados pessoais, que deverá ocorrer de forma destacada das demais cláusulas contratuais. Ressalta-se que o consentimento deve ser qualificado - o fornecedor tem o dever de prestar todas as informações relacionadas à coleta de dados, para então o consumidor poder livremente expressar a sua concordância.

O inc. X do art. $7^{\mathrm{O}}$ da Lei $\mathrm{n}^{\mathrm{O}}$ 12.965/2014 dispõe sobre o direito ao esquecimento ${ }^{118}$. O dispositivo trata do direito à exclusão definitiva dos dados pessoais, 
a pedido do usuário titular, ao término das relações entre as partes. Essa previsão obriga o responsável pela coleta e pelo tratamento do dado a apagar uma informação pessoal apenas mediante o requerimento do titular do dado. A obrigatoriedade de destruição do dado se dá somente a pedido do titular e ao término do relacionamento. Esse dispositivo não confere o direito de, como usuário, pedir a exclusão de um dado ao administrador de um site, se o usuário continuar utilizando os serviços oferecidos por este fornecedor ${ }^{119}$. Outros dispositivos da Lei $n^{-}$12.965/2014 tratam da remoção de conteúdo ${ }^{120}$.

$\mathrm{O}$ art. 7º, XIII, da Lei no 12.965/2014 é uma norma jurídica de abertura, que prevê expressamente a aplicação das regras de proteção e defesa do consumidor nas relações de consumo realizadas na internet. Nesse ponto, andou bem o legislador, ao reconhecer que os direitos dos consumidores devem ser preservados nas relações estabelecidas virtualmente.

$\mathrm{O}$ art. $8^{\circ}$ da Lei $\mathrm{n}^{\mathrm{o}}$ 12.965/2014 assegura que "a garantia do direito à privacidade e à liberdade de expressão nas comunicações é condição para o pleno exercício do direito de acesso à internet"121. Esse dispositivo também está de acordo com a Constituição, no que toca ao direito à privacidade, à vida privada e à proteção de dados.

O parágrafo único do art. $8^{\circ}$ da lei determina que são nulas de pleno direito as cláusulas contratuais que violem o direito à privacidade e à liberdade de expressão, tais como as que impliquem ofensa à inviolabilidade e ao sigilo das comunicações privadas pela internet ou que, em contrato de adesão, não ofereçam como alternativa ao contratante a adoção do foro brasileiro para a solução de controvérsias decorrentes de serviços prestados no Brasil ${ }^{122}$. Esse dispositivo está de acordo com a Constituição, da mesma forma que repete o entendimento encontrado no texto do CDC de que o foro é o do consumidor ${ }^{123}$.

Pode-se afirmar que o art. $8^{\circ}$ do Marco Civil da Internet dialoga com o $\mathrm{CDC}$, ao considerar nulas de pleno direito - isto é, considerar como não escritas todas as cláusulas contratuais que impliquem ofensa ao sigilo das comunicações privadas. Nesse sentido, será possível ler e interpretar os termos de uso e as políticas de privacidade dos sites da mesma forma como se leem os contratos de adesão nas relações de consumo. Significa dizer que se devem considerar como não escritas as cláusulas que impliquem em danos ao consumidor e à sua privacidade.

Doneda ressalta que "um dos pontos mais problemáticos do Marco Civil diz respeito à guarda de registro de acesso por parte dos provedores de conexão (obrigatória por um ano) e de aplicações internet (obrigatória por seis meses, de acordo com alguns aspectos como fins econômicos)" 124 . Provedores de conexão são os provedores de acesso, e provedores de aplicações são as redes sociais, os serviços de webmail, etc.

O art. 10 da Lei $n^{-}$12.965/2014 ${ }^{125}$ inicia a seção que dispõe sobre a proteção aos registros, aos dados pessoais e às comunicações privadas conforme a preservação da intimidade, da vida privada, da honra e da imagem das pessoas envolvidas. Esse dispositivo determina que o provedor responsável pela guarda de informações somente será obrigado a disponibilizar os registros de conexão e de acesso a aplicações de internet (sites), bem como dados pessoais e do conteúdo de comunicações privadas e outras informações que possam contribuir para a identificação do usuário ou do terminal, mediante ordem judicial e na forma do art. $7^{\circ}$ da mesma lei ${ }^{126}$.

$\mathrm{O}$ art. 10 da Lei $\mathrm{n}^{\mathrm{o}} 12.965 / 2014$ determina que o conteúdo das comunicações privadas somente poderá ser disponibilizado mediante ordem judicial, nas hipóteses e na forma que a lei estabelecer, respeitando-se a inviolabilidade da intimidade e da vida privada e a inviolabilidade e o sigilo das comunicações privadas. O legislador judicializou um procedimento que até agora vinha sendo tomado mediante notificação extrajudicial, conforme entendimento do Superior Tribunal de Justiça ${ }^{127}$. Pensa-se que a judicialização da disponibilização de conteúdo não é a melhor solução, pois até agora essa medida era realizada por notificação extrajudicial.

Por último, o $\S 4^{\circ}$ do art. 10 da Lei no 12.965/2014 determina que as medidas e os procedimentos de segurança e de sigilo devem ser informados pelo responsável pela provisão de serviços de forma clara e atender a padrões definidos em regulamento, respeitado o direito de confidencialidade quanto a segredos empresariais. Ainda não se sabe que padrões de segurança serão esses, tendo-se em vista que serão definidos por regulamento, nem se será elaborado um regulamento ${ }^{128}$.

$\mathrm{O}$ art. 11 da Lei $\mathrm{n}^{\mathrm{O}} 12.965 / 2014^{129}$ dispõe sobre a coleta, o armazenamento, a guarda e o tratamento de registros, de dados pessoais ou de comunicações por provedores de conexão e de aplicação de internet em território nacional. O procedimento para a apuração de infrações ao disposto no art. 11 será regulamentado por decreto a ser elaborado (art. 11, § $4^{\mathrm{O}}$ ).

$\mathrm{O}$ art. 12 da Lei $\mathrm{n}^{\mathrm{O}}$ 12.965/2014 ${ }^{130}$ determina sanções para a infração às normas previstas nos arts. 10 e 11 da lei, sem prejuízo das demais sanções cíveis, criminais ou administrativas. 
A análise da Lei no 12.965/2014 não pretende esgotar a discussão em torno da regulamentação do uso da internet no Brasil, que muito será debatida no futuro próximo. Mas é importante ressaltar que esse diploma legal confundiu duas esferas distintas, que são: (1) a internet como espaço de liberdade de expressão; e (2) a internet como espaço de exercício da liberdade de negociar no mercado de consumo. Pensa-se que teria sido mais positivo se o legislador tivesse ficado adstrito a apenas uma dessas esferas, sem confundi-las, porque não se pode proteger o excesso de liberdade de mercado em nome da liberdade de expressão, pois aí é possível ofender a dignidade da pessoa humana, princípio supremo do ordenamento jurídico brasileiro. A chave do sucesso é, de fato, a convergência da Lei no 12.965/2014 e do CDC, em sua versão atualizada pelo PLS 281/2012, no que tange aos direitos fundamentais do consumidor.

As eventuais divergências entre a lei que regulamenta o uso da internet no Brasil e o CDC, com relação ao importante tema da responsabilidade do provedor, podem ser apenas antinomias aparentes, e cabe aos juristas, usando o diálogo das fontes e a convergência de princípios, encontrar soluções de sua aplicação conjunta, harmônica e de acordo com os valores de proteção dos consumidores e dos cidadãos, consubstanciados na Constituição. Como afirma Lorenzetti ${ }^{131}$, na internet, os consumidores devem ter "no mínimo" a proteção que desfrutam off-line; nesse sentido, saúda-se a regulamentação do uso da internet no Brasil e a futura regulamentação do comércio eletrônico realizada pela atualização do $\mathrm{CDC}$, que farão o país cumprir a orientação da $\mathrm{ONU}^{132}$.

$\mathrm{Na}$ falta de uma legislação específica sobre a proteção de dados pessoais - o Anteprojeto de Lei do Ministério da Justiça sobre Proteção de Dados Pessoais ainda está em discussão ${ }^{133}$ - o Marco Civil da Internet regulamenta um pouco da experiência das leis de proteção de dados pessoais na internet existentes em outros países ${ }^{134}$. De acordo com Doneda, "o Marco Civil da Internet tem muitas regras relacionadas à proteção da privacidade"135. As disposições da Lei $n^{\mathrm{O}}$ 12.965/2014 sobre a proteção da privacidade e dos dados pessoais podem obrigar tanto o setor público, como o setor privado a se adaptarem à regulamentação do uso da internet no Brasil e a promoção da proteção dos dados pessoais, da privacidade e dos direitos da personalidade $^{136}$.

Até a entrada em vigor da Lei no $12.965 / 2014$, o Código de Defesa do Consumidor era o único diploma legislativo a regulamentar expressamente os bancos de dados, "assegurando a tutela do consumidor contra o armazenamento e a divulgação indevidos de seus dados, independentemente da existência de uma relação jurídica contratual"137. Atualmente, é preciso

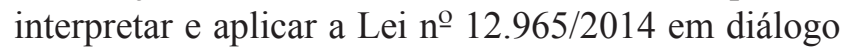
com o $\mathrm{CDC}$, procurando a solução mais favorável à proteção dos direitos do consumidor.

Por último, é necessário tecer algumas considerações sobre o Anteprojeto de Lei de Proteção de Dados Pessoais, ainda em discussão no âmbito do Poder Executivo, porque é uma norma favorável à proteção de dados e de registros pessoais.

\subsection{O Anteprojeto de Lei de Proteção de Dados Pessoais}

Embora a Lei nº 12.965/2014 contenha disposições sobre os temas de privacidade e de proteção de dados, considera-se que a questão seria mais bem resguardada com a harmonização do Marco Civil da Internet e a Lei de Proteção de Dados Pessoais em elaboração no Poder Executivo ${ }^{138}$. Uma lei específica sobre a proteção de dados pessoais é um passo imprescindível em direção a certa "civilização" no tratamento dos dados pessoais. Seria uma mensagem clara de que as empresas e os próprios governos têm que arcar com a responsabilidade de proteção de algo que é muito importante para o cidadão ${ }^{139}$.

A proteção de dados pessoais não é um problema exclusivo do direito do consumidor. É necessário estender as garantias de proteção de dados pessoais para o cidadão em todas as relações em que seus dados estejam expostos, sejam relações perante o serviço público, segmentos econômicos ou entes não econômicos ${ }^{140}$.

O Anteprojeto de Lei sobre Proteção de Dados Pessoais, apresentado em consulta pública pelo Ministério da Justiça, em novembro de $2010^{141}$, dispõe sobre a proteção de dados pessoais, a privacidade e dá outras providências ${ }^{142}$. Também, o texto prevê o respeito aos princípios gerais da proteção de dados, os requisitos, os direitos do titular, o tratamento de dados sensíveis, as regras de segurança que o setor público e o setor privado deverão cumprir, a existência de uma autoridade pública para regulamentar e administrar a aplicação da lei, as sanções administrativas e o código de boas práticas, entre outros aspectos.

$\mathrm{O}$ art. $1^{\circ}$ do Anteprojeto de Lei sobre a Proteção de Dados Pessoais ${ }^{143}$ esclarece que o objetivo é o de garantir e proteger, no âmbito do tratamento de dados pessoais, a dignidade e os direitos fundamentais da pessoa, particularmente em relação à sua liberdade, igualdade e privacidade pessoal e familiar, nos termos do art. 5ำ incisos X e XII, da Constituição. Esse dispositivo reconhece a importância da previsão constitucional e o regulamenta. 
$\mathrm{O}$ art. $2^{\mathrm{O}}$ do Anteprojeto de Lei sobre a Proteção de Dados Pessoais reconhece que "toda pessoa tem direito à proteção de seus dados pessoais"144. Aí estão incluídos todos os indivíduos, sejam eles consumidores ou não.

O art. 3 do Anteprojeto de Lei sobre a Proteção de Dados Pessoais define o âmbito de aplicação da norma e a sua não incidência, estipulando algumas exceções legais, em numerus clausus, e determinando que os bancos de dados para fins de segurança pública deverão ser regulamentados por norma específica ${ }^{145}$.

$\mathrm{O}$ art. $4^{\mathrm{o}}$ do Anteprojeto de Lei sobre a Proteção de Dados Pessoais define legalmente alguns conceitos, tais como o de dado pessoal ${ }^{146}$, o de tratamento ${ }^{147}$, o de banco de dados ${ }^{148}$, o de dados sensíveis ${ }^{149}$ e o de dados anônimos ${ }^{150}$, entre outros conceitos ${ }^{151}$.

$\mathrm{O}$ art. 5 do Anteprojeto de Lei sobre a Proteção de Dados Pessoais dispõe que "o tratamento de dados pessoais por parte de pessoas jurídicas de direito público é permitido para o cumprimento de suas funções institucionais, dentro dos limites da lei" 152 .

$\mathrm{O}$ art. $6^{\mathrm{O}}$ do Anteprojeto de Lei sobre a Proteção de Dados Pessoais determina que "o tratamento de dados pessoais é atividade de risco e todo aquele que, por meio do tratamento de dados pessoais, causar a outrem dano patrimonial, moral, individual ou coletivo, é obrigado a ressarci-lo, nos termos da lei"153.

$\mathrm{O}$ art. $7^{\circ}$ do Anteprojeto de Lei sobre a Proteção de Dados Pessoais dispõe que "a defesa dos interesses e direitos dos titulares de dados poderá ser exercida em juízo individualmente ou a título coletivo, na forma do disposto nos artigos 81 e 82 da Lei 8.078 , de 11 de setembro de 1990, na Lei 7.347 de 24 de julho de 1985 e nos demais instrumentos de tutela coletiva estabelecidos em Lei"154. Trata-se de uma norma que determina a aplicação coordenada com outras leis do ordenamento, inclusive com o CDC, o que é positivo.

O art. 8 do Anteprojeto de Lei de Proteção de Dados Pessoais ${ }^{155}$ inaugura o Capítulo II da lei, sobre os princípios gerais de proteção de dados. Entre eles, encontram-se o da finalidade (art. 8oㅡ, I), o da necessidade (art. 8ㅇ, II), o do livre acesso (art. $8^{\circ}$, III), o da proporcionalidade (art. $8^{\circ}$, IV), o da qualidade dos dados (art. $8^{\circ}, \mathrm{V}$ ), o da transparência (art. 8o, VI), o da segurança física e lógica dos dados pessoais (art. $8^{\circ}$, VII), o da boa-fé objetiva (art. $8^{\circ}$, VIII), o da responsabilidade pela reparação dos danos causados aos titulares dos dados pessoais, sejam estes patrimoniais ou morais, individuais ou coletivos (art. $8^{\mathrm{o}}$, IX), e o da prevenção, segundo o qual o responsável tem o dever de adotar, sempre que possível, medidas capazes de prevenir a ocorrência de danos em virtude do tratamento de dados pessoais (art. $8^{\circ}, \mathrm{X}$ ).
O art. $9^{\underline{0} 156}$ do Anteprojeto de Lei sobre a Proteção de Dados Pessoais inaugura o Capítulo III, sobre os requisitos para o tratamento de dados pessoais. $\mathrm{O}$ requisito fundamental, previsto no caput do art. 9으, é o consentimento livre, expresso e informado do titular, que poderá ser dado por escrito ou por outro meio que o certifique, após a notificação prévia ao titular das informações constantes no art. $11^{157}$. $\mathrm{O}$ art. 11, por sua vez, determina quais as informações que devem ser prestadas ao titular dos dados. Esse consentimento poderá ser revogado a qualquer momento (art. 10) $)^{158}$, deve figurar de forma expressa e apartada (art. 12) ${ }^{159} \mathrm{e}$ poderá ser dispensado em algumas hipóteses previstas em lei (art. 13) ${ }^{160}$. O art. 14 do Anteprojeto de Lei sobre a Proteção de Dados Pessoais determina o tratamento que deve ser conferido aos dados pessoais, estipulando uma série de requisitos legais ${ }^{161}$.

O art. 15 do Anteprojeto de Lei sobre a Proteção de Dados Pessoais inaugura o Capítulo IV, sobre os direitos do titular, que se estende até o art. 19. Os art. 20 a 22 integram o Capítulo V, sobre o tratamento que deve ser conferido aos dados sensíveis.

O Anteprojeto de Lei sobre a Proteção de Dados Pessoais possui um capítulo específico sobre a segurança dos dados que, entre outras disposições, determina a obrigação do responsável pelo tratamento de dados pessoais de adotar as medidas técnicas e organizacionais necessárias para garantir um nível adequado de segurança de dados (Capítulo VI, arts. 23 a 26), a notificação em caso de vazamento de informações (Capítulo VI, art. 27) e a responsabilização civil em caso de descumprimento das normas de proteção de dados (Capítulo I, art. $6^{\circ}$ ).

O Anteprojeto de Lei de Proteção de Dados Pessoais também dispõe sobre a comunicação e a interconexão dos dados pessoais (Capítulo VII), determinando, no art. 28, que "a comunicação ou a interconexão dos dados pessoais somente será permitida com o consentimento livre e expresso do titular e par ao cumprimento de fins diretamente relacionados com as funções legítimas do cedente e do cessionário"162. Esse dispositivo vai ao encontro da ideia de proteção de dados e de registros pessoais e a necessidade de consentimento expresso do seu titular para o seu uso constante da Lei n⿳ำ 12.965/2014, o que é positivo.

$\mathrm{O}$ art. 29, da mesma forma, possui uma norma benéfica ao indivíduo, pois determina que "o cessionário ficará sujeito às mesmas obrigações legais e regulamentares do cedente, inclusive quanto à responsabilidade solidária pelos danos eventualmente causados e ao dever de receber e processar impugnação e realizar correções" ${ }^{\prime 163}$, pois se coaduna com a ideia de responsabilidade civil solidária constante do CDC. 
Ainda, o Anteprojeto de Lei de Proteção de Dados Pessoais dispõe sobre o término do tratamento dos dados pessoais, determinando que "os dados pessoais serão cancelados quando deixarem de ser necessários ou pertinentes à finalidade que justificou sua coleta e tratamento" (Capítulo VIII, art. 30) ${ }^{164}$. Os períodos máximos para o tratamento de dados pessoais em setores e situações específicas serão regulados por lei ou regulamento posterior (art. 30, parágrafo único). Da mesma forma, o Anteprojeto dispõe sobre o tratamento de dados pessoais no setor público (Capítulo IX, arts. 32 e 33); sobre o tratamento de dados pessoais no setor privado (Capítulo X, art. 34); sobre a transferência internacional de dados (Capítulo XI, arts. 35 a 37); sobre a tutela administrativa (Título II), subdividida em autoridade de garantia (Capítulo I, arts. 38 a 40) e sanções administrativas (Capítulo II, arts. 41 a 44). Por último, dispõe sobre a possibilidade de formulação de códigos de boas práticas pelos responsáveis pelo tratamento de dados pessoais (Título III, art. 45).

Nesse sentido, faz-se necessário destacar as regras contidas no Código Brasileiro de Autorregulamentação do Marketing Direto, conhecido, também, como o Código de Ética da Associação Brasileira de Marketing Direto (ABEMD), que constitui a autorregulamentação do setor de marketing direto no Brasil. A associação entende como marketing direto "um sistema interativo que usa uma ou mais mídias para obter uma resposta ou transação mensurável em algum lugar"165. As normas do Código de Ética têm por objetivo "prover os consumidores e as organizações que atuam em marketing direto de princípios de conduta de aceitação nacional e internacional" 166 .

No Código de Ética da ABEMD, encontram-se alguns conceitos, tais como o de "lista": "3.1. Lista é um conjunto de informações individuais sobre consumidores - pessoas físicas ou jurídicas - utilizado nas atividades profissionais de Marketing Direto, e assim deverá ser definida sempre que divulgada" 167 . E há disposições sobre o respeito à privacidade do consumidor:

3.2. Os agentes de Marketing Direto que abrem a outras empresas a possibilidade de utilizar suas listas de clientes para ações de Marketing Direto devem informar tal prática ao consumidor no momento em que seus dados estiverem sendo coletados.

3.3. Os agentes de Marketing Direto devem oferecer ao consumidor a opção de ter seu nome suprimido de sua lista e providenciar a supressão para os que assim o desejarem.

3.4. Os agentes de Marketing Direto devem restringir a coleta de informações sobre o consumidor e seu compartilhamento com outras empresas aos dados adequados para fins de marketing.

3.5. Critérios de seleção e informações que possam ser consideradas de natureza pessoal ou íntima não poderão ser compartilhadas com outras empresas quando o consumidor acreditar que tais dados serão mantidos em sigilo ${ }^{168}$.

Atualmente, em função de não haver legislação específica sobre a proteção dos dados pessoais e a segurança da informação, aplicam-se as normas do Código de Defesa do Consumidor, sempre que o caso envolver relações de consumo, em conjunto com as disposições da Lei no ${ }^{-12.965 / 2014}$, no caso de relações de consumo realizadas por meios eletrônicos e a distância.

Mendes afirma:

[...] é possível aplicarem-se as normas do Código de Defesa do Consumidor (CDC), sempre que o caso se enquadrar nos conceitos de consumidor ou consumidor equiparado, conforme o art. $2^{-}$, caput e parágrafo único, arts. 17 e 29 do CDC. Da responsabilidade objetiva do fornecedor de serviços, estabelecida no art. 14 do CDC, é possível inferir-se a obrigação do fornecedor de propiciar a segurança adequada e suficiente aos bancos de dados e cadastros sob a sua responsabilidade. Com base no art. $6^{\circ}, \mathrm{VI}$, do CDC, extrai-se que o fornecedor responde pelos danos materiais e morais oriundos da falha de segurança. Assim, decorre do risco da atividade de processamento de dados pessoais o dever do fornecedor de manter sistemas seguros, que protejam os dados pessoais em relação à sua confidencialidade, integridade e disponibilidade ${ }^{169}$.

De acordo com Doneda, o texto do Anteprojeto de Lei de Proteção de Dados Pessoais proposto pelo Ministério da Justiça procurou estar alinhado com algumas técnicas, formatos e princípios presentes em legislações estrangeiras ${ }^{170}$. Na opinião do autor, "a existência de uma legislação específica de proteção de dados no país ajudará o Brasil a entrar no jogo mundial da transferência de dados, a ser mais competitivo"171. Doneda afirma que tanto o Marco Civil da Internet no Brasil quanto a Lei de Proteção de Dados Pessoais obrigarão as empresas públicas e privadas a fazer investimentos para se adequarem ao arcabouço legal ${ }^{172}$.

O tema da proteção dos dados pessoais está regulado, também, em dispositivos da Lei de Acesso à Informação (Lei no 12.527/2011) e da Lei do Cadastro Positivo (Lei no 12.414/2011).

No Senado Federal, destacam-se alguns projetos de lei em tramitação: o Projeto de Lei do Senado nº 181, 
de 2014, que estabelece princípios, garantias, direitos e obrigações referentes à proteção de dados pessoais; o Projeto de Lei do Senado no 407, de 2013, que altera o art. 43 do Código de Defesa do Consumidor para dispor sobre a natureza, a finalidade e o acesso às informações dos bancos de dados e cadastros relativos a consumidores; o Projeto de Lei do Senado no 330, de 2013, que dispõe sobre a proteção, o tratamento e o uso dos dados pessoais, e dá outras providências; o Projeto de Lei do Senado no 85, de 2009 (no 836/2003, na Câmara dos Deputados, do Senhor Deputado Bernardo Ariston), que disciplina o funcionamento de bancos de dados e serviços de proteção ao crédito e congêneres e dá outras providências, que tramitou em conjunto com o PLS 281/2012, mas retornou para a Comissão de Meio Ambiente, Defesa do Consumidor e Fiscalização e Controle (CMA) do Senado Federal, em 3 de setembro de 2014; o Projeto de Lei da Câmara dos Deputados no 4.060, de 2012, do Deputado Milton Monti, que dispõe sobre o tratamento de dados pessoais e dá outras providências.

Há, ainda, pelo menos três decretos presidenciais que abordam a proteção de dados pessoais, conforme destacou Mendes. São eles: o Decreto no 6.135/2007, que dispõe sobre o cadastro único para programas sociais do Governo Federal; o Decreto no 6.425/2008, que dispõe sobre o Censo Anual da Educação; e o Decreto $\mathrm{n}^{\mathrm{o}} 6.523 / 2008$, que regulamenta o CDC para fixar normas gerais sobre o Serviço de Atendimento ao Consumidor (SAC) ${ }^{173}$.

\section{CONCLUSÃO}

Conforme se verificou, sustenta-se que a proteção de dados deve estar embasada nos princípios constitucionais da dignidade da pessoa humana, do respeito à vida privada, à privacidade e à liberdade da pessoa, porque são informações que dizem respeito à sua intimidade. $\mathrm{O}$ valor supremo da dignidade da pessoa humana limita o alcance de qualquer regramento jurídico e justifica a existência e a proteção dos direitos da personalidade.

A proteção dos dados e dos registros pessoais tem sido debatida no cenário jurídico nacional, principalmente depois da entrada em vigor da Lei $\mathrm{n}^{\mathrm{o}} 12.965 / 2014$, que regulamenta o uso da internet no Brasil, porque os aplicadores do Direito deverão ter o cuidado de não retroceder nos direitos e nas garantias alcançados pelo ordenamento jurídico brasileiro ao aplicar essa legislação. Por isso, sugere-se uma aplicação conjunta, um "diálogo das fontes" entre o Código de Defesa do Consumidor e a Lei $\mathrm{n}^{\mathrm{o}}$ $12.965 / 2014$, à luz do princípio da dignidade da pessoa humana, assegurado pela Constituição, bem como o princípio da vulnerabilidade do consumidor, garantido pelo CDC, e baseada no princípio da proibição do retrocesso dos direitos fundamentais. A existência de um Anteprojeto de Lei de Proteção de Dados Pessoais denota a importância que a sociedade confere ao tema, pois a matéria está em discussão e será regulamentada.

\section{REFERÊNCIAS}

Anteprojeto de Lei de Proteção de Dados Pessoais. Disponível em: $<$ http://www.acessoainformacao.gov.br/menu-de-apoio/recursospasso-a-passo/anteprojeto-lei-protecao-dados-pessoais.pdf $>$. Acesso em: 19 set. 2014.

ASCENSÃO, José de Oliveira. O direito de autor no ciberespaço. Revista da Ajuris, Porto Alegre, v. 26, n. 80, p. 334-353, dez. 2000.

BESSA, Leonardo Roscoe. Abrangência da disciplina conferida pelo Código de Defesa do Consumidor aos bancos de dados de proteção ao crédito. In: NERY JUNIOR, Nelson; NERY, Rosa Maria de Andrade (Org.). Responsabilidade civil: direito à informação: dever de informação, informações cadastrais, mídia, informação e poder, internet. São Paulo: Revista dos Tribunais, 2010. v. 8. (Doutrinas essenciais). p. 393-419.

BESSA, Leonardo Roscoe. Cadastro positivo: comentários à Lei 12.414, de 9 de junho de 2011. São Paulo: Revista dos Tribunais, 2011.

BESSA, Leonardo Roscoe. Limites jurídicos dos bancos de dados de proteção ao crédito. In: MARQUES, Claudia Lima; MIRAGEM, Bruno (Org.). Direito do consumidor: proteção da confiança e práticas comerciais: publicidade, dever de informar, concorrência e mercado e consumo, práticas comerciais abusivas, ... São Paulo: Revista dos Tribunais, 2011. v. 3. (Doutrinas essenciais). p. 10391061.

BESSA, Leonardo Roscoe. O Consumidor e os limites dos bancos de dados de proteção ao crédito. São Paulo: Revista dos Tribunais, 2003.

BRASIL. Decreto no 7.962, de 15 de março de 2013. Regulamenta a Lei no 8.078 , de 11 de setembro de 1990, para dispor sobre a contratação no comércio eletrônico. Disponível em: <http://www. planalto.gov.br/CCIVIL_03/_Ato2011-2014/2013/Decreto/D7962. htm>. Acesso em: 19 set. $20 \overline{1} 4$.

BRASIL. Lei no 12.965 , de 23 de abril de 2014. Estabelece princípios, garantias, direitos e deveres para o uso da Internet no Brasil. Disponível em: <http:/www.planalto.gov.br/CCIVIL 03/ Ato2011-2014/2014/Lei/L12965.htm>. Acesso em: 19 set. 2014.

BRASIL. Lei no 8.078 , de 11 de setembro de 1990. Dispõe sobre a proteção do consumidor e dá outras providências. Disponível em: $<$ http://www.planalto.gov.br/ccivil_03/Leis/L8078.htm>. Acesso em: 23 set. 2014.

BRASIL. Lei no 9.507, de 12 de novembro de 1997. Regula o direito de acesso a informações e disciplina o rito processual do habeas data. Disponível em: <http://www.planalto.gov.br/ccivil_03/Leis/ L9507.htm>. Acesso em: 21 set. 2014.

BRASIL. Senado Federal. Atualização do Código de Defesa do Consumidor: anteprojetos: relatório. Brasília: [s.n.], [2012].

BRASIL. Senado Federal. Parecer no 243, de 2014. Da Comissão Temporária de Modernização do Código de Defesa do Consumidor, sobre os Projetos de Lei nos 281,282 e 283, de 2012, todos do Senador José Sarney, que alteram o Código de Defesa do Consumidor sobre comércio eletrônico, as ações coletivas, crédito ao consumidor e superendividamento. Disponível em: <http://www.senado.gov.br/ atividade $/$ materia/getPDF.asp? $\mathrm{t}=148162 \& \mathrm{tp}=1>$. Acesso em: 19 set. 2014. 
BRASIL. Superior Tribunal de Justiça. Quarta Turma, Recurso Especial no 1.021.987/RN, Relator Ministro Fernando Gonçalves, julgado em 7 out. 2008.

BRASIL. Superior Tribunal de Justiça. Quarta Turma, Recurso Especial no 22.337/RS, Relator Ministro Ruy Rosado de Aguiar Júnior, julgado em 13 fev. 1995.

BRASIL. Superior Tribunal de Justiça. Terceira Turma, Agravo Regimental no Recurso Especial no ${ }^{\mathrm{o}}$ 1.325.220/MG, Relator Ministro Paulo de Tarso Vieira Sanseverino, julgado em 18 jun. 2013.

BRASIL. Superior Tribunal de Justiça. Terceira Turma, Agravo Regimental no Agravo em Recurso Especial no ${ }^{\circ}$ 118.179/RS, Relator Ministro Sidnei Beneti, julgado em 20 mar. 2012.

BRASIL. Superior Tribunal de Justiça. Terceira Turma, Recurso Especial no 1.077.911/SP, Relatora Ministra Nancy Andrighi, julgado em 4 out. 2011.

BRASIL. Superior Tribunal de Justiça. Terceira Turma, Recurso Especial no 1.308.830/RS, Relatora Ministra Nancy Andrighi, julgado em 8 maio 2012.

BRASIL. Superior Tribunal de Justiça. Terceira Turma, Recurso Especial no 1.323.754/RJ, Relatora Ministra Nancy Andrighi, julgado em 19 jun. 2012.

CARVALHO, Ana Paula Gambogi. O consumidor e o direito à autodeterminação informacional: considerações sobre os bancos de dados eletrônicos. In: NERY JUNIOR, Nelson; NERY, Rosa Maria de Andrade (Org.). Responsabilidade civil: direito à informação: dever de informação, informações cadastrais, mídia, informação e poder, internet. São Paulo: Revista dos Tribunais, 2010. v. 8. (Doutrinas essenciais). p. 343-392.

CASTRO JÚNIOR, Marco Aurélio de. A uniformização de tratamento das relações jurídicas travadas na Internet. Revista dos Mestrados em Direito Econômico da Universidade Federal da Bahia, Salvador, Edição especial, p. 215-227, jan.-dez. 1998.

CASTRO, Luiz Fernando Martins. Proteção de dados pessoais: internacional e brasileiro. Revista CEJ, Brasília, n. 19, p. 40-45, out.-dez. 2002.

Código de Ética da ABEMD. Disponível em: < http://www.abemd. org.br/pagina.php?id=23>. Acesso em: 19 set. 2014.

COSTA, Carlos Celso Orcesi da. Cadastro positivo: Lei $\mathrm{n}^{\mathrm{o}}$ 12.414/2011 comentada artigo por artigo. São Paulo: Saraiva, 2012.

DONEDA, Danilo. Considerações sobre a tutela da privacidade e a proteção de dados pessoais no ordenamento brasileiro. In: CONRADO, Marcelo; PINHEIRO, Rosalice Fidalgo (Coord.). Direito privado e Constituição: ensaios para uma recomposição valorativa da pessoa e do patrimônio. Curitiba: Juruá, 2009. p. 87-107.

DONEDA, Danilo. Da privacidade à proteção de dados pessoais. Rio de Janeiro: Renovar, 2006.

DONEDA, Danilo. O direito fundamental à proteção de dados pessoais. In: MARTINS, Guilherme Magalhães (Coord.). Direito Privado e Internet: atualizado pela Lei no 12.965/2014: Marco Civil da Internet no Brasil. São Paulo: Atlas, 2014. p. 61-78.

DONEDA, Danilo. Um código para a proteção de dados pessoais na Itália. Revista Trimestral de Direito Civil, Rio de Janeiro, ano 4, n. 16, p. 117-133, out.-dez. 2003.

EFING, Antônio Carlos. Bancos de dados e cadastro de consumidores. São Paulo: Revista dos Tribunais, 2002.

JABUR, Gilberto Haddad. Desautorizada comercialização de dados pessoais para envio de mala-direta e a violação à privacidade. Revista do Instituto dos Advogados de São Paulo (RIASP), São Paulo, nova série, ano 16, n. 31, p. 301-331, jan.-jun. 2013.

KLEE, Antonia Espíndola Longoni. A atualização do Código de Defesa do Consumidor: o Projeto de Lei do Senado no 281/2012 sobre o comércio eletrônico e a proteção do consumidor na Internet. Revista Jurídica, Porto Alegre, ano 60, n. 420, p. 9-52, out. 2012.
KLEE, Antonia Espíndola Longoni. Comércio Eletrônico. São Paulo: Revista dos Tribunais, 2014.

LAEBER, Márcio Rafael Silva. Proteção de dados pessoais: o direito à autodeterminação informativa. Revista de Direito Bancário e do Mercado de Capitais, São Paulo, n. 37, p. 59, jul. 2007.

LIMBERGER, Têmis. O direito à intimidade na era da informática: a necessidade de proteção dos dados pessoais. Porto Alegre: Livraria do Advogado, 2007.

LIMBERGER, Têmis. Proteção dos dados pessoais e comércio eletrônico: os desafios do século XXI. Revista de Direito do Consumidor, São Paulo, ano 17, n. 67, p. 215-241, jul.-set. 2008.

LISBOA, Roberto Senise. O consumidor na sociedade da informação. Revista de Direito do Consumidor, São Paulo, ano 16, n. 61, p. 203-229, jan.-mar. 2007.

LORENZETTI, Ricardo Luis. Comércio eletrônico. Tradução de Fabiano Menke. Notas de Claudia Lima Marques. São Paulo: Revista dos Tribunais, 2004.

Manifestação do Brasilcon e as Propostas da Comissão Especial do Brasilcon de Acompanhamento do Projeto de Atualização do Código de Defesa do Consumidor sobre comércio eletrônico em <http://www.senado.gov.br/atividade/materia/getPDF. asp? $\mathrm{t}=121282 \& \mathrm{tp}=1>$. Acesso em: 20 mar. 2013.

MARQUES, Claudia Lima (Coord.). Diálogo das Fontes: do conflito à coordenação de normas do direito brasileiro. São Paulo: Revista dos Tribunais, 2012.

MARQUES, Claudia Lima. A atualização do Código de Defesa do Consumidor (Palestra). O comércio eletrônico e suas implicações (Painel). Seminário sobre a regulamentação do comércio eletrônico no Brasil. Rio de Janeiro, RJ, Palácio do Comércio, Auditório da Associação Comercial do Estado do Rio de Janeiro (ACRJ), 14 de setembro de 2012.

MARQUES, Claudia Lima. Introdução ao direito do consumidor. In: BENJAMIN, Antônio Herman de Vasconcellos e; MARQUES, Claudia Lima; BESSA, Leonardo Roscoe. Manual de direito do consumidor. 5. ed. rev., atual. e ampl. São Paulo: Revistados Tribunais, 2014. p. 31-54.

MARQUES, Claudia Lima. Novos temas na teoria dos contratos: confiança e o conjunto contratual. Revista da Ajuris, Porto Alegre, ano 32, n. 100, p. 73-97, dez. 2005.

MARQUES, Claudia Lima. O “diálogo das fontes” como método da nova teoria geral do direito: um tributo a Erik Jayme. In: MARQUES, Claudia Lima (Coord.). Diálogo das fontes: do conflito à coordenação de normas do direito brasileiro. São Paulo: Revista dos Tribunais, 2012. p. 17-66.

MARQUES, Claudia Lima; BENJAMIN, Antônio Herman V; MIRAGEM, Bruno. Comentários ao Código de Defesa do Consumi dor. 4. ed. rev., atual. e ampl. São Paulo: Revista dos Tribunais, 2013.

MARQUES, Claudia Lima; KLEE, Antonia Espíndola Longoni. Os direitos do consumidor e a regulamentação do uso da internet no Brasil: convergência no direito às informações claras e completas nos contratos de prestação de serviços de internet. In: LEITE, George Salomão; LEMOS, Ronaldo (Coord.). Marco Civil da Internet. São Paulo: Atlas, 2014. p. 469-517.

MARTINS, Guilherme Magalhães. Formação dos contratos eletrônicos de consumo via Internet. 2 . ed. rev. e atual. Rio de Janeiro: Forense, 2010.

MARTINS, Guilherme Magalhães. O direito ao esquecimento na Internet. In: MARTINS, Guilherme Magalhães (Coord.). Direito privado e internet. São Paulo: Atlas, 2014. p. 3-28.

MAZZEI, Rodrigo Reis; CAMBLER, Everaldo Augusto; BARRETO, Wanderlei de Paula; DANTAS, Marcelo Navarro Ribeiro; TERRA, Marcelo. Comentários ao Código Civil brasileiro: parte geral: arts. $1^{\mathrm{O}}$ a 103 . Coordenadores Arruda Alvim e Thereza Alvim. Rio de Janeiro: Forense, 2005. v. 1. 
MENDES, Laura Schertel. O direito fundamental à proteção de dados pessoais. Revista de Direito do Consumidor, São Paulo, ano 20, n. 79, p. 45 e seguintes, jul.-set. 2011.

MENDES, Laura Schertel. Privacidade, proteção de dados e defesa do consumidor: linhas gerais de um novo direito fundamental. São Paulo: Saraiva, 2014.

MENDES, Laura Schertel. Segurança da informação, proteção de dados pessoais e confiança. Revista de Direito do Consumidor, São Paulo, ano 22, n. 90, p. 245-260, nov.-dez. 2013.

MENDES, Laura Schertel. Transparência e privacidade: violação e proteção da informação pessoal na sociedade de consumo. Disponível em: <http://repositorio.unb.br/bitstream/10482/4782/1/ DISSERTACAO\%20LAURA.pdf>. Acesso em: 16 set. 2014.

MIRAGEM, Bruno. Curso de Direito do Consumidor. 4. ed., rev., atual. e ampl. São Paulo: Revista dos Tribunais, 2013.

MONTEIRO FILHO, Raphael de Barros; MONTEIRO, Ralpho Waldo de Barros; MONTEIRO, Ronaldo de Barros; MONTEIRO, Ruy Carlos de Barros. Comentários ao novo Código Civil: das pessoas: arts. $1^{\mathrm{O}}$ a 78. Coordenador Sálvio de Figueiredo Teixeira. Rio de Janeiro: Forense, 2010. v. 1.

NERY, Ana Luíza B. de Andrade Fernandes. Considerações sobre os bancos de dados de proteção ao crédito no Brasil. In: NERY JUNIOR, Nelson; NERY, Rosa Maria de Andrade (Org.). Responsabilidade civil: direito à informação: dever de informação, informações cadastrais, mídia, informação e poder, internet. São Paulo: Revista dos Tribunais, 2010. v. 8. (Doutrinas essenciais). p. $421-438$.

O Marco Civil e a proteção dos seus dados pessoais: o que muda? Disponível em: <http://idgnow.com.br/blog/circuito/2014/04/29/omarco-civil-e-a-protecao-dos-seus-dados-pessoais-o-que-muda/> . Acesso em: 19 set. 2014.

OLIVEIRA, Carlos Eduardo Elias de. Aspectos principais da Lei $n^{\circ}$ 12.965, de 2014, o Marco Civil da Internet: subsídios à comunidade jurídica. Brasília: Núcleo de Estudos e Pesquisas/CONLEG/ Senado, abr. 2014 (Texto para Discussão no 148). Disponível em: $<$ http://www.senado.leg.br/estudos>. Acesso em: 29 abr. 2014.

ONU. Assembleia Geral. Promotion And Protection Of All Human Rights, Civil, Political, Economic, Social And Cultural Rights, Including The Right To Development: The Promotion, Protection And Enjoyment Of Human Rights On The Internet. A/HRC/20/L.13,
29.6.2013. Disponível em: <http://www.regeringen.se/content/1/ c6/19/64/51/6999c512.pdf>. Acesso em: 8 maio 2014.

OVILLA BUENO, Rocío. Internet y derecho. De la realidad virtual a la realidad jurídica. Boletín Mexicano de Derecho Comparado, México, UNAM, n. 92, p. 421-438, mayo-ago. 1998.

PFEIFFER, Roberto Augusto Castellanos. PLS 281: proteção do consumidor no comércio eletrônico. Disponível em: $<$ http://www. senado.gov.br/atividade/materia/getPDF.asp?t=116238\&tp=1>. Acesso em: 27 ago. 2013.

RODRIGUES JUNIOR, Otavio Luiz. Direito de apagar dados e a decisão do tribunal europeu no caso Google Espanha. Disponível em: <http://www.conjur.com.br/2014-mai-21/direito-apagardados-decisao-tribunal-europeu-google-espanha>. Acesso em: 19 set. 2014

RODRIGUES JUNIOR, Otávio Luiz. Direito de apagar dados e a decisão do tribunal europeu no caso Google Espanha (Parte 2). Disponível em: <http:/www.conjur.com.br/2014-mai-28/direitocomparado-direito-apagar-dados-decisao-tribunal-europeu-googleespanha>. Acesso em: 19 set. 2014.

RONCOLATO, Murilo. Depois do Marco Civil, projetos buscam cobrir lacunas da internet brasileira. Disponível em: <http://blogs. estadao.com.br/link/depois-do-marco-civil-projetos-buscamcobrir-lacunas-da-internet-brasileira/> . Acesso em: 19 set. 2014.

SAMPAIO, José Adércio Leite. Direito à intimidade e à vida privada: uma visão jurídica da sexualidade, da família, da comunicação e informações pessoais, da vida e da morte. Belo Horizonte: Del Rey, 1998.

SANTOLIM, Cesar Viterbo Matos. Anotações sobre o Anteprojeto da Comissão de Juristas para a atualização do Código de Defesa do Consumidor na parte referente ao comércio eletrônico. Revista de Direito do Consumidor, São Paulo, v. 83, p. 73-82, jul. 2012.

SANTOS, Maria Cecília de Andrade. Contratos informáticos: breve estudo. Revista dos Tribunais, São Paulo, ano 88, v. 762, p. 32-66, abr. 1999.

TAKAHASHI, Tadao (Org.). Sociedade da informação no Brasil: livro verde. Brasília: Ministério da Ciência e Tecnologia, 2000.

WARREN, Samuel D.; BRANDEIS, Louis D. The Right to Privacy. Harvard Law Review, Cambridge, v. 4, n. 5, Dece. 1890. Disponível em: <http://faculty.uml.edu/sgallagher/Brandeisprivacy.htm>. Acesso em: 19 set. 2014.

\section{NOTAS}

1 MENDES, Laura Schertel. O direito fundamental à proteção de dados pessoais. Revista de Direito do Consumidor, São Paulo, ano 20, n. 79, p. 45 , jul.-ago. 2011.

A autora afirma que o conceito de privacidade evoluiu da discussão sobre a violação do direito de imagem de celebridades fotografadas por paparazzi nas mais diversas situações cotidianas ao debate sobre o risco à personalidade dos milhares de cidadãos cujos dados pessoais são coletados, processados e transferidos por órgãos públicos e privados, valendo-se das modernas tecnologias de informação.

2 SAMPAIO, José Adércio Leite. Direito à intimidade e à vida privada: uma visão jurídica da sexualidade, da família, da comunicação e informações pessoais, da vida e da morte. Belo Horizonte: Del Rey, 1998. p. 550.

3 SAMPAIO, José Adércio Leite. Direito à intimidade e à vida privada: uma visão jurídica da sexualidade, da família, da comunicação e informações pessoais, da vida e da morte. Belo Horizonte: Del Rey, 1998. p. 550.

4 DONEDA, Danilo. Um código para a proteção de dados pessoais na Itália. Revista Trimestral de Direito Civil, Rio de Janeiro, ano 4, n. 16, p. 118 , out.-dez. 2003.

5 MENDES, Laura Schertel. O direito fundamental à proteção de dados pessoais. Revista de Direito do Consumidor, São Paulo, ano 20, n. 79, p. 45 , jul.-ago. 2011
6 MENDES, Laura Schertel. O direito fundamental à proteção de dados pessoais. Revista de Direito do Consumidor, São Paulo, ano 20, n. 79, p. 45 , jul.-set. 2011 .

MENDES, Laura Schertel. O direito fundamental à proteção de dados pessoais. Revista de Direito do Consumidor, São Paulo, ano 20, n. 79, p. 45, jul.-set. 2011.

No mesmo sentido, ver CASTRO, Luiz Fernando Martins. Proteção de dados pessoais: internacional e brasileiro. Revista CEJ, Brasília, n. 19, p. 41, out.-dez. 2002.

8 MENDES, Laura Schertel. O direito fundamental à proteção de dados pessoais. Revista de Direito do Consumidor, São Paulo, ano 20, n. 79, p. 45, jul.-ago. 2011.

Para mais informações sobre a criação e o surgimento da internet, ver MARTINS, Guilherme Magalhães. Formação dos contratos eletrônicos de consumo via Internet. 2. ed. rev. e atual. Rio de Janeiro: Forense, 2010 .

Ver, também, KLEE, Antonia Espíndola Longoni. Comércio Eletrônico. São Paulo: Revista dos Tribunais, 2014. p. 61-66.

9 KLEE, Antonia Espíndola Longoni. Comércio Eletrônico. São Paulo: Revista dos Tribunais, 2014. p. 35, 43 e 73.

10 MENDES, Laura Schertel. O direito fundamental à proteção de dados pessoais. Revista de Direito do Consumidor, São Paulo, ano 20, n. 79, p. 45 , jul.-set. 2011. 
11 MENDES, Laura Schertel. O direito fundamental à proteção de dados pessoais. Revista de Direito do Consumidor, São Paulo, ano 20, n. 79, p. 45, jul.-ago. 2011.

12 MENDES, Laura Schertel. O direito fundamental à proteção de dados pessoais. Revista de Direito do Consumidor, São Paulo, ano 20, n. 79, p. 45, jul.-ago. 2011.

13 MENDES, Laura Schertel. Transparência e privacidade: violação e proteção da informação pessoal na sociedade de consumo. Disponível em: $<$ http://repositorio.unb.br/bitstream/10482/4782/1/DISSERTACAO $\% 20$ LAURA.pdf $>$. Acesso em: 16 set. 2014.

Da mesma forma, ver MENDES, Laura Schertel. O direito fundamental à proteção de dados pessoais. Revista de Direito do Consumidor, São Paulo, ano 20, n. 79, p. 45, jul.-set. 2011.

14 JABUR, Gilberto Haddad. Desautorizada comercialização de dados pessoais para envio de mala-direta e a violação à privacidade. Revista do Instituto dos Advogados de São Paulo (RIASP), São Paulo, nova série, ano 16, n. 31, p. 305, jan.-jun. 2013.

15 Para os comentários aos arts. 11 a 21 do Código Civil, sobre os direitos da personalidade, ver MAZZEI, Rodrigo Reis; CAMBLER, Everaldo Augusto; BARRETO, Wanderlei de Paula; DANTAS, Marcelo Navarro Ribeiro; TERRA, Marcelo. Comentários ao Código Civil brasileiro: parte geral: arts. $1^{\circ}$ a 103. Coordenadores Arruda Alvim e Thereza Alvim. Rio de Janeiro: Forense, 2005. v. 1, p. 99-220.

Ver, também, MONTEIRO FILHO, Raphael de Barros; MONTEIRO, Ralpho Waldo de Barros; MONTEIRO, Ronaldo de Barros; MONTEIRO, Ruy Carlos de Barros. Comentários ao novo Código Civil: das pessoas: arts. $1^{\circ}$ a 78 . Coordenador Sálvio de Figueiredo Teixeira. Rio de Janeiro: Forense, 2010. v. 1, p. 124-268.

16 Ver DONEDA, Danilo. Da privacidade à proteção de dados pessoais. Rio de Janeiro: Renovar, 2006.

17 JABUR, Gilberto Haddad. Desautorizada comercialização de dados pessoais para envio de mala-direta e a violação à privacidade. Revista do Instituto dos Advogados de São Paulo (RIASP), São Paulo, nova série, ano 16, n. 31, p. 304, jan.-jun. 2013.

18 JABUR, Gilberto Haddad. Desautorizada comercialização de dados pessoais para envio de mala-direta e a violação à privacidade. Revista do Instituto dos Advogados de São Paulo (RIASP), São Paulo, nova série, ano 16, n. 31, p. 304, jan.-jun. 2013.

19 Right to be left alone, expressão criada em 1878, pelo Juiz da Suprema Corte norte-americana Thomas Cooley, em seu Treatise on the Law of Torts 29. Depois, passou a ser chamado de right to privacy, por Louis Brandeis e Samuel Warren. Ver MENDES, Laura Schertel. O direito fundamental à proteção de dados pessoais. Revista de Direito do Consumidor, São Paulo, ano 20, n. 79, p. 45, jul.-set. 2011; JABUR, Gilberto Haddad. Desautorizada comercialização de dados pessoais para envio de mala-direta e a violação à privacidade. Revista do Instituto dos Advogados de São Paulo (RIASP), São Paulo, nova série, ano 16, n. 31, p. 304, jan.-jun. 2013; DONEDA, Danilo. Da privacidade à proteção de dados pessoais. Rio de Janeiro: Renovar, 2006. p. 1.

20 JABUR, Gilberto Haddad. Desautorizada comercialização de dados pessoais para envio de mala-direta e a violação à privacidade. Revista do Instituto dos Advogados de São Paulo (RIASP), São Paulo, nova série, ano 16, n. 31, p. 313, jan.-jun. 2013.

21 JABUR, Gilberto Haddad. Desautorizada comercialização de dados pessoais para envio de mala-direta e a violação à privacidade. Revista do Instituto dos Advogados de São Paulo (RIASP), São Paulo, nova série, ano 16, n. 31, p. 313, jan.-jun. 2013.

22 Para uma explicação detalhada do método "diálogo das fontes", ver MARQUES, Claudia Lima. O "diálogo das fontes" como método da nova teoria geral do direito: um tributo a Erik Jayme. In: MARQUES, Claudia Lima (Coord.). Diálogo das fontes: do conflito à coordenação de normas do direito brasileiro. São Paulo: Revista dos Tribunais, 2012. p. 17-66.

23 Anteprojeto de Lei de Proteção de Dados Pessoais. Disponível em: $<$ http://www.acessoainformacao.gov.br/menu-de-apoio/recursos-passoa-passo/anteprojeto-lei-protecao-dados-pessoais.pdf>. Acesso em: 19 set. 2014.

24 SAMPAIO, José Adércio Leite. Direito à intimidade e à vida privada: uma visão jurídica da sexualidade, da família, da comunicação e informações pessoais, da vida e da morte. Belo Horizonte: Del Rey, 1998. p. 478.

25 Art. 5º da Constituição da República de 1988. Todos são iguais perante a lei, sem distinção de qualquer natureza, garantindo-se aos brasileiros e aos estrangeiros residentes no País a inviolabilidade do direito à vida, à liberdade, à igualdade, à segurança e à propriedade, nos termos seguintes: $[\ldots]$;
X - são invioláveis a intimidade, a vida privada, a honra e a imagem das pessoas, assegurado o direito à indenização pelo dano material ou moral decorrente de sua violação;

$[\ldots]$.

26 Art. 5o da Constituição da República de 1988. [...].

$[\ldots]$

XII - é inviolável o sigilo da correspondência e das comunicações telegráficas, de dados e das comunicações telefônicas, salvo, no último caso, por ordem judicial, nas hipóteses e na forma que a lei estabelecer para fins de investigação criminal ou instrução processual penal; [...].

27 Para um histórico da evolução da proteção dos dados pessoais, ver DONEDA, Danilo. Da privacidade à proteção de dados pessoais. Rio de Janeiro: Renovar, 2006.

Ver, também, DONEDA, Danilo. Um código para a proteção de dados pessoais na Itália. Revista Trimestral de Direito Civil, Rio de Janeiro, ano 4, n. 16, p. 117-133, out.-dez. 2003.

Ainda, ver CARVALHO, Ana Paula Gambogi. O consumidor e o direito à autodeterminação informacional: considerações sobre os bancos de dados eletrônicos. In: NERY JUNIOR, Nelson; NERY, Rosa Maria de Andrade (Org.). Responsabilidade civil: direito à informação: dever de informação, informações cadastrais, mídia, informação e poder, internet. São Paulo: Revista dos Tribunais, 2010. v. 8. (Doutrinas essenciais). p. 372-377.

28 Art. 5o da Constituição da República de 1988. [...].

$[\ldots]$

LXXII - conceder-se-á habeas data:

a) para assegurar o conhecimento de informações relativas à pessoa do impetrante, constantes de registros ou bancos de dados de entidades governamentais ou de caráter público;

b) para a retificação de dados, quando não se prefira fazê-lo por processo sigiloso, judicial ou administrativo;

$[\ldots]$.

Para uma análise sobre o habeas data no direito brasileiro como elemento para a proteção de dados pessoais, ver DONEDA, Danilo. Da privacidade à proteção de dados pessoais. Rio de Janeiro: Renovar, 2006. p. 326-337.

29 CASTRO, Luiz Fernando Martins. Proteção de dados pessoais: internacional e brasileiro. Revista CEJ, Brasília, n. 19, p. 43, out.-dez. 2002.

30 BRASIL. Lei no 9.507, de 12 de novembro de 1997. Regula o direito de acesso a informações e disciplina o rito processual do habeas data. Disponível em: <http://www.planalto.gov.br/ccivil_03/Leis/L9507. htm>. Acesso em: 21 set. 2014.

${ }^{31}$ CASTRO, Luiz Fernando Martins. Proteção de dados pessoais: internacional e brasileiro. Revista CEJ, Brasília, n. 19, p. 43, out.-dez. 2002.

32 WARREN, Samuel D.; BRANDEIS, Louis D. The Right to Privacy. Harvard Law Review, Cambridge, v. 4, n. 5, December 1890. Disponível em: <http://faculty.uml.edu/sgallagher/Brandeisprivacy.htm>. Acesso em: 19 set. 2014.

Para o estudo detalhado da influência do artigo de Warren e Brandeis para a evolução do conceito de privacidade, ver SAMPAIO, José Adércio Leite. Direito à intimidade e à vida privada: uma visão jurídica da sexualidade, da família, da comunicação e informações pessoais, da vida e da morte. Belo Horizonte: Del Rey, 1998. p. 493-496; MENDES, Laura Schertel. O direito fundamental à proteção de dados pessoais. Revista de Direito do Consumidor, São Paulo, ano 20, n. 79, p. 45, jul.-set. 2011; JABUR, Gilberto Haddad. Desautorizada comercialização de dados pessoais para envio de mala-direta e a violação à privacidade. Revista do Instituto dos Advogados de São Paulo (RIASP), São Paulo, nova série, ano 16, n. 31, p. 304, jan.-jun. 2013; LIMBERGER, Têmis. Proteção dos dados pessoais e comércio eletrônico: os desafios do século XXI. Revista de Direito do Consumidor, São Paulo, ano 17, n. 67, p. 221-222, nota 23, jul./set. 2008; CARVALHO, Ana Paula Gambogi. O consumidor e o direito à autodeterminação informacional: considerações sobre os bancos de dados eletrônicos. In: NERY JUNIOR, Nelson; NERY, Rosa Maria de Andrade (Org.). Responsabilidade civil: direito à informação: dever de informação, informações cadastrais, mídia, informação e poder, internet. São Paulo: Revista dos Tribunais, 2010. v. 8. (Doutrinas essenciais). p. 345-349.

33 SAMPAIO, José Adércio Leite. Direito à intimidade e à vida privada: uma visão jurídica da sexualidade, da família, da comunicação e informações pessoais, da vida e da morte. Belo Horizonte: Del Rey, 1998. p. 493.

34 SAMPAIO, José Adércio Leite. Direito à intimidade e à vida privada: uma visão jurídica da sexualidade, da família, da comunicação e 
informações pessoais, da vida e da morte. Belo Horizonte: Del Rey, 1998. p. 493-494.

35 SAMPAIO, José Adércio Leite. Direito à intimidade e à vida privada: uma visão jurídica da sexualidade, da família, da comunicação e informações pessoais, da vida e da morte. Belo Horizonte: Del Rey, 1998. p. 494.

36 OVILLA BUENO, Rocío. Internet y derecho. De la realidad virtual a la realidad jurídica. Boletín Mexicano de Derecho Comparado, México, UNAM, n. 92, p. 421, mayo-ago. 1998.

Informação é tudo o que é alvo de conhecimento humano, suscetível de ser comunicado, tratado e armazenado; todo fato ou dado capaz de transportar conhecimento. SANTOS, Maria Cecília de Andrade. Contratos informáticos: breve estudo. Revista dos Tribunais, São Paulo, ano 88, v. 762, p. 33, abr. 1999 .

A informação é um bem; não basta ter a informação, é preciso saber utilizá-la, tratá-la, transformá-la; tudo é informação. Ver CASTRO JÚNIOR, Marco Aurélio de. A uniformização de tratamento das relações jurídicas travadas na Internet. Revista dos Mestrados em Direito Econômico da Universidade Federal da Bahia, Salvador, p. 217-218, jan./dez. 1998. Edição Especial.

"No mundo moderno, informação é sinônimo de poder". CASTRO, Luiz Fernando Martins. Proteção de dados pessoais: internacional e brasileiro. Revista CEJ, Brasília, n. 19, p. 41, out.-dez. 2002.

${ }^{37}$ LISBOA, Roberto Senise. O consumidor na sociedade da informação. Revista de Direito do Consumidor, São Paulo, ano 16, n. 61, p. 208, jan.-mar. 2007.

38 LISBOA, Roberto Senise. O consumidor na sociedade da informação. Revista de Direito do Consumidor, São Paulo, ano 16, n. 61, p. 208, jan.-mar. 2007.

39 KLEE, Antonia Espíndola Longoni. Comércio Eletrônico. São Paulo: Revista dos Tribunais, 2014. p. 40.

${ }^{40}$ ASCENSÃO, José de Oliveira. O direito de autor no ciberespaço. Revista da Ajuris, Porto Alegre, vol. 26, n. 80, p. 335, dez. 2000.

MARQUES, citando Kloepfer, menciona que "a informação é um poder e o que se almeja hoje na sociedade é a 'equidade informacional"', com base na boa-fé e cooperando com o outro. MARQUES, Claudia Lima. Novos temas na teoria dos contratos: confiança e o conjunto contratual. Revista da Ajuris, Porto Alegre, ano 32, n. 100, p. 95, dez. 2005.

No Brasil, há mais de dez anos o Governo tem a preocupação de promover a universalização do acesso e o uso crescente dos meios eletrônicos de informação, pois reconhece que a sociedade brasileira vive na era da tecnologia da informação. Ver TAKAHASHI, Tadao (Org.). Sociedade da informação no Brasil: livro verde. Brasília: Ministério da Ciência e Tecnologia, 2000.

${ }^{41}$ SAMPAIO, José Adércio Leite. Direito à intimidade e à vida privada: uma visão jurídica da sexualidade, da família, da comunicação e informações pessoais, da vida e da morte. Belo Horizonte: Del Rey, 1998. p. 494-495.

42 SAMPAIO, José Adércio Leite. Direito à intimidade e à vida privada: uma visão jurídica da sexualidade, da família, da comunicação e informações pessoais, da vida e da morte. Belo Horizonte: Del Rey, 1998. p. 495.

${ }^{43}$ SAMPAIO, José Adércio Leite. Direito à intimidade e à vida privada: uma visão jurídica da sexualidade, da família, da comunicação e informações pessoais, da vida e da morte. Belo Horizonte: Del Rey, 1998. p. 495.

${ }^{44}$ LIMBERGER, Têmis. Proteção dos dados pessoais e comércio eletrônico: os desafios do século XXI. Revista de Direito do Consumidor, São Paulo, ano 17, n. 67, p. 218, jul.-set. 2008.

${ }^{45}$ MENDES, Laura Schertel. Segurança da informação, proteção de dados pessoais e confiança. Revista de Direito do Consumidor, São Paulo, ano 22, n. 90, p. 249, nov.-dez. 2013

46 MENDES, Laura Schertel. Segurança da informação, proteção de dados pessoais e confiança. Revista de Direito do Consumidor, São Paulo, ano 22, n. 90, p. 249, nov.-dez. 2013.

47 SAMPAIO, José Adércio Leite. Direito à intimidade e à vida privada: uma visão jurídica da sexualidade, da família, da comunicação e informações pessoais, da vida e da morte. Belo Horizonte: Del Rey, 1998. p. 519. Para o estudo do panorama legislativo estrangeiro, ver MENDES, Laura Schertel. Privacidade, proteção de dados e defesa do consumidor: linhas gerais de um novo direito fundamental. São Paulo: Saraiva, 2014.

Também, ver DONEDA, Danilo. Da privacidade à proteção de dados pessoais. Rio de Janeiro: Renovar, 2006. p. 221-306.

48 Para um exame mais detalhado sobre o direito à autodeterminação informativa, ver LAEBER, Márcio Rafael Silva. Proteção de dados pessoais: o direito à autodeterminação informativa. Revista de Direito Bancário e do Mercado de Capitais, São Paulo, n. 37, p. 59, jul. 2007. Ver, também, CARVALHO, Ana Paula Gambogi. O consumidor e o direito à autodeterminação informacional: considerações sobre os bancos de dados eletrônicos. In: NERY JUNIOR, Nelson; NERY, Rosa Maria de Andrade (Org.). Responsabilidade civil: direito à informação: dever de informação, informações cadastrais, mídia, informação e poder, internet. São Paulo: Revista dos Tribunais, 2010. v. 8. (Doutrinas essenciais). p. 343-392.

${ }^{49}$ LIMBERGER, Têmis. Proteção dos dados pessoais e comércio eletrônico: os desafios do século XXI. Revista de Direito do Consumidor, São Paulo, ano 17, n. 67, p. 225, jul.-set. 2008.

Ver, também, CARVALHO, Ana Paula Gambogi. O consumidor e o direito à autodeterminação informacional: considerações sobre os bancos de dados eletrônicos. In: NERY JUNIOR, Nelson; NERY, Rosa Maria de Andrade (Org.). Responsabilidade civil: direito à informação: dever de informação, informações cadastrais, mídia, informação e poder, internet São Paulo: Revista dos Tribunais, 2010. v. 8. (Doutrinas essenciais). p. 343-392.

${ }^{50}$ LIMBERGER, Têmis. Proteção dos dados pessoais e comércio eletrônico: os desafios do século XXI. Revista de Direito do Consumidor, São Paulo, ano 17, n. 67, p. 225, jul.-set. 2008

${ }^{51}$ Para uma explicação detalhada dos modelos de controle, ver SAMPAIO, José Adércio Leite. Direito à intimidade e à vida privada: uma visão jurídica da sexualidade, da família, da comunicação e informações pessoais, da vida e da morte. Belo Horizonte: Del Rey, 1998. p. 522-533.

52 JABUR, Gilberto Haddad. Desautorizada comercialização de dados pessoais para envio de mala-direta e a violação à privacidade. Revista do Instituto dos Advogados de São Paulo (RIASP), São Paulo, nova série, ano 16, n. 31, p. 317, jan.-jun. 2013.

${ }_{53}$ Os dados sensíveis são as informações pessoais cujo tratamento possa ensejar discriminação do titular, tais como aqueles que revelem a origem racial ou étnica, as convicções religiosas, filosóficas ou morais, as opiniões políticas, a filiação sindical, partidária ou a organizações de caráter religioso, filosófico ou político, os referentes à saúde e à vida sexual, bem como os dados genéticos e biométricos.

Para um exame mais detalhado, ver MENDES, Laura Schertel. Privacidade, proteção de dados e defesa do consumidor: linhas gerais de um novo direito fundamental. São Paulo: Saraiva, 2014. p. 72-77.

${ }^{54}$ DONEDA, Danilo. Considerações sobre a tutela da privacidade e a proteção de dados pessoais no ordenamento brasileiro. In: CONRADO, Marcelo; PINHEIRO, Rosalice Fidalgo (Coord.). Direito privado e Constituição: ensaios para uma recomposição valorativa da pessoa e do patrimônio. Curitiba: Juruá, 2009. p. 87.

55 BRASIL. Senado Federal. Parecer no 243 , de 2014. Da Comissão Temporária de Modernização do Código de Defesa do Consumidor, sobre os Projetos de Lei n⿳⺈⿴囗十一 281,282 e 283, de 2012, todos do Senador José Sarney, que alteram o Código de Defesa do Consumidor sobre comércio eletrônico, as ações coletivas, crédito ao consumidor e superendividamento. Disponível em: $<\mathrm{http}: / / w w w . s e n a d o . g o v \cdot b r /$ atividade/materia/getPDF.asp?t=148162\&tp=1>. Acesso em: 19 set. 2014.

56 Anteprojeto de Lei de Proteção de Dados Pessoais. Disponível em: $<$ http://www.acessoainformacao.gov.br/menu-de-apoio/recursos-passoa-passo/anteprojeto-lei-protecao-dados-pessoais.pdf>. Acesso em: 19 set. 2014.

${ }^{57}$ Art. 48 do Ato das Disposições Constitucionais Transitórias. O Congresso Nacional, dentro de cento e vinte dias da promulgação da Constituição, elaborará código de defesa do consumidor.

58 Art. $5^{\circ}$ Todos são iguais perante a lei, sem distinção de qualquer natureza, garantindo-se aos brasileiros e aos estrangeiros residentes no País a inviolabilidade do direito à vida, à liberdade, à igualdade, à segurança e à propriedade, nos termos seguintes:

$[\ldots]$;

XXXII - o Estado promoverá, na forma da lei, a defesa do consumidor; $[\ldots]$.

${ }^{59}$ MARQUES, Claudia Lima. Introdução ao direito do consumidor. In: BENJAMIN, Antônio Herman de Vasconcellos e; MARQUES, Claudia Lima; BESSA, Leonardo Roscoe. Manual de direito do consumidor. 5. ed. rev., atual. e ampl. São Paulo: Revista dos Tribunais, 2013. p. 51.

${ }^{60}$ Art. 43 do CDC. O consumidor, sem prejuízo do disposto no art. 86, terá acesso às informações existentes em cadastros, fichas, registros e dados pessoais e de consumo arquivados sobre ele, bem como sobre as suas respectivas fontes.

$\S 1^{\mathrm{o}}$ Os cadastros e dados de consumidores devem ser objetivos, claros, verdadeiros e em linguagem de fácil compreensão, não podendo conter informações negativas referentes a período superior a cinco anos. $\S 2^{\mathrm{O}}$ A abertura de cadastro, ficha, registro e dados pessoais e de consumo deverá ser comunicada por escrito ao consumidor, quando não solicitada por ele. 
$\S 3^{\mathrm{o}} \mathrm{O}$ consumidor, sempre que encontrar inexatidão nos seus dados e cadastros, poderá exigir sua imediata correção, devendo o arquivista, no prazo de cinco dias úteis, comunicar a alteração aos eventuais destinatários das informações incorretas.

$\S 4^{\circ}$ Os bancos de dados e cadastros relativos a consumidores, os serviços de proteção ao crédito e congêneres são considerados entidades de caráter público.

$\S 5^{\text {o }}$ Consumada a prescrição relativa à cobrança de débitos do consumidor, não serão fornecidas, pelos respectivos Sistemas de Proteção ao Crédito, quaisquer informações que possam impedir ou dificultar novo acesso ao crédito junto aos fornecedores.

BRASIL. Lei no 8.078 , de 11 de setembro de 1990. Dispõe sobre a proteção do consumidor e dá outras providências. Disponível em: $<$ http:// www.planalto.gov.br/ccivil 03/Leis/L8078.htm>. Acesso em: 23 set. 2014.

${ }^{61}$ STJ. REsp 22.337/RS. Quarta Turma, Relator Ministro Ruy Rosado de Aguiar Júnior, julgado em 13 fev. 1995. Ementa: "Serviço de proteção ao crédito. Cancelamento do registro. Prazo (cinco anos). O registro de dados no SPC deve ser cancelado após cinco anos. Art. 43, parágrafo $1^{\circ}$, do Código de Defesa do Consumidor (Lei 8.078/90)". Disponível em: <https://ww2.stj.jus.br/processo/ita/documento/mediado/?num registro $=199200114466 \& \mathrm{dt}$ publicacao $=20-03-1995 \& \operatorname{cod}$ tipo documento $=>$. Acesso em: 19 set. 2014.

${ }^{62}$ Para um exame detalhado da importância do art. 43 do CDC para a proteção de dados, ver MENDES, Laura Schertel. O direito fundamental à proteção de dados pessoais. Revista de Direito do Consumidor, São Paulo, ano 20, n. 79, p. 45, jul.-set. 2011.

Ver, também, DONEDA, Danilo. Da privacidade à proteção de dados pessoais. Rio de Janeiro: Renovar, 2006. p. 204-205.

${ }^{63}$ AGUIAR JÚNIOR, Ruy Rosado de. Voto. STJ. RESp 22.337/RS. Quarta Turma, Relator Ministro Ruy Rosado de Aguiar Júnior, julgado em 13 fev. 1995. Disponível em: <https:/ww2.stj.jus.br/processo/ita/ documento $/$ mediado/?num_registro $=199200114466 \& d t$ publicacao $=20$ 03-1995\&cod tipo documento $=>$. Acesso em: 19 set. 2014.

${ }^{64}$ BESSA, Leonardo Roscoe. O consumidor e os limites dos bancos de dados de proteção ao crédito. São Paulo: Revista dos Tribunais, 2003.

BESSA, Leonardo Roscoe. Limites jurídicos dos bancos de dados de proteção ao crédito. In: MARQUES, Claudia Lima; MIRAGEM, Bruno (Org.). Direito do consumidor: proteção da confiança e práticas comerciais: publicidade, dever de informar, concorrência e mercado e consumo, práticas comerciais abusivas, ... São Paulo: Revista dos Tribunais, 2011. v. 3. (Doutrinas essenciais). p. 1039-1061.

BESSA, Leonardo Roscoe. Abrangência da disciplina conferida pelo Código de Defesa do Consumidor aos bancos de dados de proteção ao crédito. In: NERY JUNIOR, Nelson; NERY, Rosa Maria de Andrade (Org.). Responsabilidade civil: direito à informação: dever de informação, informações cadastrais, mídia, informação e poder, internet. São Paulo: Revista dos Tribunais, 2010. v. 8. (Doutrinas essenciais). p. 393-419.

65 EFING, Antônio Carlos. Bancos de dados e cadastro de consumidores. São Paulo: Revista dos Tribunais, 2002.

66 LIMBERGER, Têmis. O direito à intimidade na era da informática: a necessidade de proteção dos dados pessoais. Porto Alegre: Liv. do Advogado, 2007.

NERY, Ana Luíza B. de Andrade Fernandes. Considerações sobre os bancos de dados de proteção ao crédito no Brasil. In: NERY JUNIOR, Nelson; NERY, Rosa Maria de Andrade (Org.). Responsabilidade civil: direito à informação: dever de informação, informações cadastrais, mídia, informação e poder, internet. São Paulo: Revista dos Tribunais, 2010. v. 8. (Doutrinas essenciais). p. 421-438.

CARVALHO, Ana Paula Gambogi. O consumidor e o direito à autodeterminação informacional: considerações sobre os bancos de dados eletrônicos. In: NERY JUNIOR, Nelson; NERY, Rosa Maria de Andrade (Org.). Responsabilidade civil: direito à informação: dever de informação, informações cadastrais, mídia, informação e poder, internet. São Paulo: Revista dos Tribunais, 2010. v. 8. (Doutrinas essenciais). p. 343-392.

67 DONEDA, Danilo. Considerações sobre a tutela da privacidade e a proteção de dados pessoais no ordenamento brasileiro. In: CONRADO, Marcelo; PINHEIRO, Rosalice Fidalgo (Coord.). Direito privado e Constituição: ensaios para uma recomposição valorativa da pessoa e do patrimônio. Curitiba: Juruá, 2009. p. 103.

68 Art. 39 do CDC. É vedado ao fornecedor de produtos ou serviços, dentre outras práticas abusivas:

$[\ldots]$;

III - enviar ou entregar ao consumidor, sem solicitação prévia, qualquer produto, ou fornecer qualquer serviço; $[\ldots]$.

BRASIL. Lei no 8.078, de 11 de setembro de 1990. Dispõe sobre a proteção do consumidor e dá outras providências. Disponível em: <http://www. planalto.gov.br/ccivil_03/Leis/L8078.htm>. Acesso em: 23 set. 2014.

69 JABUR, Gilberto Haddad. Desautorizada comercialização de dados pessoais para envio de mala-direta e a violação à privacidade. Revista do Instituto dos Advogados de São Paulo (RIASP), São Paulo, nova série, ano 16, n. 31, p. 317, jan.-jun. 2013.

70 Ver ementa do julgado: "Agravo Regimental no Agravo em Recurso Especial. Indenização. Danos morais. Inscrição do nome do autor em banco de dados mantido em desacordo com os ditames previstos nos artigos 39 , VII, e 43 , caput, e $\$ \S 1^{\circ}$ e $3^{\circ}$, do Código de Defesa do Consumidor. Conclusão do acórdão recorrido baseada em análise de fatos. Revisão obstada em sede de recurso especial. Súmula STJ/07. 1. Tendo o acórdão recorrido concluído que a agravante criou banco de dados com informações pessoais do autor, sem a devida publicização, inviabilizando os direitos de amplo acesso às informações concernentes à pessoa do consumidor e de reclamar por eventuais ilegalidades ou incorreções, gerando, inclusive, provável restrição de crédito, diante do escore desfavorável, caracterizado está o dano in re ipsa. Verifica-se que a convicção a que chegou o aresto decorreu da análise do conjunto fáticoprobatório, e o acolhimento da pretensão recursal demandaria o reexame do mencionado suporte, obstando a admissibilidade do especial à luz da Súmula 7 desta Corte. 2. Agravo Regimental improvido". BRASIL. Superior Tribunal de Justiça. Terceira Turma, Agravo Regimental no Agravo em Recurso Especial no $118.179 /$ RS, Relator Ministro Sidnei Beneti, julgado em 20 mar. 2012. Disponível em: <http://www.stj.jus. $\mathrm{br} / \mathrm{SCON} / \mathrm{jurisprudencia/toc.jsp}$ ?tipo_visualizacao $=$ null\&livre $=\mathrm{CDC}$ $90+\mathrm{MESMO}+\mathrm{ART}+\mathrm{ADJ}+\% 2700043 \% 27 \& \mathrm{ref}=\mathrm{CDC}-90+\mathrm{MESMO}+\mathrm{A}$ $\mathrm{RT}+\mathrm{ADJ}+\% 2700039 \% 27 \& \mathrm{~b}=\mathrm{ACOR} \&$ thesaurus $=\mathrm{JURIDICO}>$. Acesso em: 23 set. 2014.

Ver, também, MARQUES, Claudia Lima; BENJAMIN, Antônio Herman V.; MIRAGEM, Bruno. Comentários ao Código de Defesa do Consumidor. 4. ed. rev., atual. e ampl. São Paulo: Revista dos Tribunais, 2013. p. 978-1017.

71 MIRAGEM, Bruno. Curso de Direito do Consumidor. 4. ed., rev., atual. e ampl. São Paulo: Revista dos Tribunais, 2013. p. 295.

72 BRASIL. Senado Federal. Parecer no 243, de 2014. Da Comissão Temporária de Modernização do Código de Defesa do Consumidor, sobre os Projetos de Lei nº ${ }^{\circ}$ 281, 282 e 283, de 2012, todos do Senador José Sarney, que alteram o Código de Defesa do Consumidor sobre comércio eletrônico, as ações coletivas, crédito ao consumidor e superendividamento. Disponível em: <http://www.senado.gov.br/ atividade/materia/getPDF.asp? $\mathrm{t}=148162 \& \mathrm{tp}=1>$. Acesso em: 19 set. 2014.

73 Sobre o tema, ver MENDES, Laura Schertel. Privacidade, proteção de dados e defesa do consumidor: linhas gerais de um novo direito fundamental. São Paulo: Saraiva, 2014.

74 BRASIL. Senado Federal. Parecer no ${ }^{\circ} 243$, de 2014. Da Comissão Temporária de Modernização do Código de Defesa do Consumidor, sobre os Projetos de Lei n⿳⺈ ${ }^{\mathrm{o}}$ 281, 282 e 283, de 2012, todos do Senado José Sarney, que alteram o Código de Defesa do Consumidor, sobre o comércio eletrônico, as ações coletivas, crédito ao consumidor e superendividamento. Disponível em: <http://www.senado.gov.br/ atividade/materia/getPDF.asp?t=148162\&tp=1>. Acesso em: 19 set. 2014.

${ }^{75}$ SANTOLIM, Cesar Viterbo Matos. Anotações sobre o Anteprojeto da Comissão de Juristas para a atualização do Código de Defesa do Consumidor na parte referente ao comércio eletrônico. Revista de Direito do Consumidor, São Paulo, v. 83, p. 75, jul. 2012.

76 A Comissão de Juristas foi criada em 2.12.2010, pelo Ato do Presidente n 305. O mandato da Comissão foi renovado até 31.3.2012, pelos Atos do Presidente n⿳0 308, de 2010, n⿳⺈ 115, de 2011, e n⿳⺈ 206, de 2011. Nesse período, a Comissão de Juristas foi presidida pelo Ministro do STJ Antônio Herman de Vasconcellos e Benjamin e contou com a participação da Prof. Dra. Claudia Lima Marques (Relatora-Geral), dos professores doutores Ada Pellegrini Grinover, Leonardo Roscoe Bessa, Roberto Augusto Castellanos Pefeiffer e Kazuo Watanabe. Foi assessorada no plano técnico-jurídico por Wellerson Miranda Pereira. O Relatório-Geral da Comissão pode ser lido em BRASIL. Senado Federal. Atualização do Código de Defesa do Consumidor: anteprojetos: relatório. Brasília: [s.n.], [2012]. Ver, em especial, p. 27 e ss.

Ver KLEE, Antonia Espíndola Longoni. Comércio Eletrônico. São Paulo: Revista dos Tribunais, 2014. p. 245, nota 125.

Ver, também, KLEE, Antonia Espíndola Longoni. A atualização do Código de Defesa do Consumidor: o Projeto de Lei do Senado no 281/2012 sobre o comércio eletrônico e a proteção do consumidor na 
Internet. Revista Jurídica, Porto Alegre, ano 60, n. 420, p. 9-52, out. 2012.

${ }^{77}$ MARQUES, Claudia Lima. A atualização do Código de Defesa do Consumidor (Palestra). O comércio eletrônico e suas implicações (Painel). Seminário sobre a regulamentação do comércio eletrônico no Brasil. Rio de Janeiro, RJ, Palácio do Comércio, Auditório da Associação Comercial do Estado do Rio de Janeiro (ACRJ), 14 de setembro de 2012.

${ }^{78} \mathrm{KLEE}$, Antonia Espíndola Longoni. Comércio Eletrônico. São Paulo: Revista dos Tribunais, 2014. p. 261.

79 Art. 44-A do CDC, conforme proposto pelo Projeto de Lei do Senado no $281 / 2012$, na forma de seu substitutivo, que incluiu a expressão "e a distância", por sugestão da Comissão Especial de Acompanhamento dos Projetos de Atualização do CDC, do Brasilcon.

BRASIL. Senado Federal. Parecer no 243, de 2014. Da Comissão Temporária de Modernização do Código de Defesa do Consumidor, sobre os Projetos de Lei n⿳⺈ ${ }^{\mathrm{S}} 281,282$ e 283, de 2012, todos do Senado José Sarney, que alteram o Código de Defesa do Consumidor, sobre o comércio eletrônico, as ações coletivas, crédito ao consumidor e superendividamento. Disponível em: <http://www.senado.gov.br/ atividade/materia/getPDF.asp?t=148162\&tp=1>. Acesso em: 19 set. 2014.

Ver a Manifestação do Brasilcon e as Propostas da Comissão Especial do Brasilcon de Acompanhamento do Projeto de Atualização do Código de Defesa do Consumidor sobre comércio eletrônico em <http://www. senado.gov.br/atividade/materia/getPDF.asp? $\mathrm{t}=121282 \& \mathrm{tp}=1>$. Acesso em: 20 mar. 2013.

80 PFEIFFER, Roberto Augusto Castellanos. PLS 281: proteção do consumidor no comércio eletrônico. Disponível em: <http://www. senado.gov.br/atividade/materia/getPDF.asp?t=116238\&tp=1>. Acesso em: 27 ago. 2013.

${ }^{81}$ Ver, por exemplo, a decisão no REsp no $1.077 .911 / \mathrm{SP}$, cuja ementa é a que segue: "Consumidor. Contrato. Seguro. Apólice não emitida. Aceitação do seguro. Responsabilidade. Seguradora e Corretores. Cadeia de fornecimento. Solidariedade. 1. A melhor exegese dos arts. 14 e 18 do CDC indica que todos aqueles que participam da introdução do produto ou serviço no mercado devem responder solidariamente por eventual defeito ou vício, isto é, imputa-se a toda a cadeia de fornecimento a responsabilidade pela garantia de qualidade e adequação. 2. O art. 34 do CDC materializa a teoria da aparência, fazendo com que os deveres de boa-fé, cooperação, transparência e informação alcancem todos os fornecedores, direitos ou indiretos, principais ou auxiliares, enfim todos aqueles que, aos olhos do consumidor, participem da cadeia de fornecimento. 3. No sistema do CDC fica a critério do consumidor a escolha dos fornecedores solidários que irão integrar o polo passivo da ação. Poderá exercitar sua pretensão contra todos ou apenas contra alguns desses fornecedores, conforme sua comodidade e/ou conveniência. [...]. 6. Recurso especial não provido".

BRASIL. Superior Tribunal de Justiça. Terceira Turma, Recurso Especial

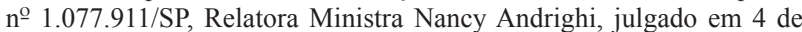
outubro de 2011.

82 Passagem retirada da ementa do julgado. BRASIL. Superior Tribunal de Justiça. Quarta Turma, Recurso Especial no 1.021.987/RN, Relator Ministro Fernando Gonçalves, julgado em 7.10.2008.

${ }^{83}$ KLEE, Antonia Espíndola Longoni. Comércio Eletrônico. São Paulo: Revista dos Tribunais, 2014. p. 276.

${ }^{84} \mathrm{KLEE}$, Antonia Espíndola Longoni. Comércio Eletrônico. São Paulo: Revista dos Tribunais, 2014. p. 276-277.

${ }^{85}$ Anteprojeto de Lei de Proteção de Dados Pessoais. Disponível em: $<$ http://www.acessoainformacao.gov.br/menu-de-apoio/recursos-passoa-passo/anteprojeto-lei-protecao-dados-pessoais.pdf>. Acesso em: 19 set. 2014.

${ }^{86}$ BRASIL. Senado Federal. Parecer $n^{\circ}$ 243, de 2014. Da Comissão Temporária de Modernização do Código de Defesa do Consumidor, sobre os Projetos de Lei $\mathrm{n}^{\mathrm{S}} \mathrm{S} 281,282$ e 283, de 2012, todos do Senado José Sarney, que alteram o Código de Defesa do Consumidor, sobre o comércio eletrônico, as ações coletivas, crédito ao consumidor e superendividamento. Disponível em: <http://www.senado.gov.br/ atividade/materia/getPDF.asp?t=148162\&tp=1>. Acesso em: 19 set. 2014.

${ }^{87}$ Doneda ensina: “[...] dados que revelam informações sobre uma pessoa que podem potencialmente dar origem à discriminação caso sejam conhecidos por terceiros". DONEDA, Danilo. Considerações sobre a tutela da privacidade e a proteção de dados pessoais no ordenamento brasileiro. In: CONRADO, Marcelo; PINHEIRO, Rosalice Fidalgo (Coord.). Direito privado e Constituição: ensaios para uma recomposição valorativa da pessoa e do patrimônio. Curitiba: Juruá, 2009. p. 99.
88 Art. 72-A do PLS 281/2012, na forma de seu substitutivo. Veicular, exibir, licenciar, alienar, compartilhar, doar ou de qualquer forma ceder ou transferir dados, informações ou identificadores pessoais, sem a expressa autorização de seu titular e consentimento informado.

Pena - Detenção, de três meses a um ano, e multa.

Parágrafo Único. Não constitui crime a prática dos atos previstos no caput:

I - entre fornecedores que integrem um mesmo conglomerado econômico; II - em razão de determinação, requisição ou solicitação de órgão público.

BRASIL. Senado Federal. Parecer no 243, de 2014. Da Comissão Temporária de Modernização do Código de Defesa do Consumidor, sobre os Projetos de Lei $\mathrm{n}^{\circ} \mathrm{s}$ 281, 282 e 283, de 2012, todos do Senado José Sarney, que alteram o Código de Defesa do Consumidor, sobre o comércio eletrônico, as ações coletivas, crédito ao consumidor e superendividamento. Disponível em: <http://www.senado.gov.br/ atividade/materia/getPDF.asp?t=148162\&tp=1>. Acesso em: 19 set. 2014.

${ }^{89}$ BRASIL. Senado Federal. Atualização do Código de Defesa do Consumidor: anteprojetos: relatório. Brasília: [s.n.], [2012]. p. 105.

${ }^{90}$ BRASIL. Decreto no 7.962, de 15 de março de 2013. Regulamenta a Lei no 8.078 , de 11 de setembro de 1990, para dispor sobre a contratação no comércio eletrônico. Disponível em: <http://www.planalto.gov.br/ CCIVIL_03/_Ato2011-2014/2013/Decreto/D7962.htm>. Acesso em: 19 set. 2014

91 Para uma explicação detalhada do método "diálogo das fontes", ver MARQUES, Claudia Lima. O "diálogo das fontes" como método da nova teoria geral do direito: um tributo a Erik Jayme. In: MARQUES, Claudia Lima (Coord.). Diálogo das fontes: do conflito à coordenação de normas do direito brasileiro. São Paulo: Revista dos Tribunais, 2012. p. 17-66.

92 Para um exame detalhado da Lei no 12.414 , de 2011, ver: BESSA, Leonardo Roscoe. Cadastro positivo: comentários à Lei 12.414, de 9 de junho de 2011. São Paulo: Revista dos Tribunais, 2011.

Também, ver: COSTA, Carlos Celso Orcesi da. Cadastro positivo: Lei no 12.414/2011 comentada artigo por artigo. São Paulo: Saraiva, 2012.

93 KLEE, Antonia Espíndola Longoni. Comércio Eletrônico. São Paulo: Revista dos Tribunais, 2014. p. 285-286.

94 BRASIL. Lei oㅜ 12.965, de 23 de abril de 2014. Estabelece princípios, garantias, direitos e deveres para o uso da Internet no Brasil. Disponível em: <http://www.planalto.gov.br/CCIVIL 03/_Ato2011-2014/2014/Lei/ L12965.htm>. Acesso em: 19 set. 2014.

${ }^{95}$ MARQUES, Claudia Lima; KLEE, Antonia Espíndola Longoni. Os direitos do consumidor e a regulamentação do uso da internet no Brasil: convergência no direito às informações claras e completas nos contratos de prestação de serviços de internet. In: LEITE, George Salomão; LEMOS, Ronaldo (Coord.). Marco Civil da Internet. São Paulo: Atlas, 2014. p. 485

96 Art. 32. Esta Lei entra em vigor após decorridos 60 (sessenta) dias de sua publicação oficial.

BRASIL. Lei no ${ }^{-12.965}$, de 23 de abril de 2014. Estabelece princípios, garantias, direitos e deveres para o uso da Internet no Brasil. Disponível em: <http://www.planalto.gov.br/CCIVIL 03/ Ato2011-2014/2014/Lei/ L12965.htm>. Acesso em: 19 set. 2014.

${ }^{97}$ Art. $1^{\circ}$ Esta Lei estabelece princípios, garantias, direitos e deveres para o uso da internet no Brasil e determina as diretrizes para atuação da União, dos Estados, do Distrito Federal e dos Municípios em relação à matéria. BRASIL. Lei nº 12.965, de 23 de abril de 2014. Estabelece princípios, garantias, direitos e deveres para o uso da Internet no Brasil. Disponível em: <http://www.planalto.gov.br/CCIVIL_03/_Ato2011-2014/2014/Lei/ L12965.htm>. Acesso em: 19 set. 2014.

98 Art. $2^{\mathrm{o}}$ A disciplina do uso da internet no Brasil tem como fundamento o respeito à liberdade de expressão, bem como: I - o reconhecimento da escala mundial da rede;

II - os direitos humanos, o desenvolvimento da personalidade e o exercício da cidadania em meios digitais;

III - a pluralidade e a diversidade;

IV - a abertura e a colaboração;

$\mathrm{V}$ - a livre iniciativa, a livre concorrência e a defesa do consumidor; e VI - a finalidade social da rede.

BRASIL. Lei no 12.965, de 23 de abril de 2014. Estabelece princípios, garantias, direitos e deveres para o uso da Internet no Brasil. Disponível em: <http://www.planalto.gov.br/CCIVIL 03/_Ato2011-2014/2014/Lei/ L12965.htm>. Acesso em: 19 set. 2014.

${ }^{99}$ Art. $3^{\mathrm{O}}$ A disciplina do uso da internet no Brasil tem os seguintes princípios: 
I - garantia da liberdade de expressão, comunicação e manifestação de pensamento, nos termos da Constituição Federal;

II - proteção da privacidade;

III - proteção dos dados pessoais, na forma da lei;

IV - preservação e garantia da neutralidade de rede;

$\mathrm{V}$ - preservação da estabilidade, segurança e funcionalidade da rede, por meio de medidas técnicas compatíveis com os padrões internacionais e pelo estímulo ao uso de boas práticas;

VI - responsabilização dos agentes de acordo com suas atividades, nos termos da lei;

VII - preservação da natureza participativa da rede;

VIII - liberdade dos modelos de negócios promovidos na internet, desde que não conflitem com os demais princípios estabelecidos nesta Lei. Parágrafo único. Os princípios expressos nesta Lei não excluem outros previstos no ordenamento jurídico pátrio relacionados à matéria ou nos tratados internacionais em que a República Federativa do Brasil seja parte.

BRASIL. Lei no 12.965, de 23 de abril de 2014. Estabelece princípios, garantias, direitos e deveres para o uso da Internet no Brasil. Disponível em: <http://www.planalto.gov.br/CCIVIL 03/ Ato2011-2014/2014/Lei/ L12965.htm>. Acesso em: 19 set. 2014.

${ }^{100}$ Anteprojeto de Lei de Proteção de Dados Pessoais. Disponível em: $<$ http://www.acessoainformacao.gov.br/menu-de-apoio/recursos-passoa-passo/anteprojeto-lei-protecao-dados-pessoais.pdf>. Acesso em: 19 set. 2014.

${ }^{101} \mathrm{O}$ Marco Civil e a proteção dos seus dados pessoais: o que muda? Disponível em: <http://idgnow.com.br/blog/circuito/2014/04/29/omarco-civil-e-a-protecao-dos-seus-dados-pessoais-o-que-muda/>. Acesso em: 19 set. 2014.

${ }^{102}$ O Marco Civil e a proteção dos seus dados pessoais: o que muda? Disponível em: <http://idgnow.com.br/blog/circuito/2014/04/29/omarco-civil-e-a-protecao-dos-seus-dados-pessoais-o-que-muda/ $>$. Acesso em: 19 set. 2014.

${ }^{103}$ O Marco Civil e a proteção dos seus dados pessoais: o que muda? Disponível em: <http://idgnow.com.br/blog/circuito/2014/04/29/omarco-civil-e-a-protecao-dos-seus-dados-pessoais-o-que-muda/>. Acesso em: 19 set. 2014.

${ }^{104}$ O Marco Civil e a proteção dos seus dados pessoais: o que muda? Disponível em: <http://idgnow.com.br/blog/circuito/2014/04/29/omarco-civil-e-a-protecao-dos-seus-dados-pessoais-o-que-muda/ $>$. Acesso em: 19 set. 2014.

${ }^{105}$ Anteprojeto de Lei de Proteção de Dados Pessoais. Disponível em: $<$ http://www.acessoainformacao.gov.br/menu-de-apoio/recursos-passoa-passo/anteprojeto-lei-protecao-dados-pessoais.pdf $>$. Acesso em: 19 set. 2014.

${ }^{106}$ RONCOLATO, Murilo. Depois do Marco Civil, projetos buscam cobrir lacunas da internet brasileira. Disponível em: <http://blogs.estadao. com.br/link/depois-do-marco-civil-projetos-buscam-cobrir-lacunas-dainternet-brasileira/>. Acesso em: 19 set. 2014.

${ }^{107}$ A expressão "diálogo das fontes" é de Erik Jayme, e foi disseminada no Brasil por Claudia Lima Marques. Ver MARQUES, Claudia Lima (Coord.). Diálogo das Fontes: do conflito à coordenação de normas do direito brasileiro. São Paulo: Revista dos Tribunais, 2012.

${ }^{108}$ MARQUES, Claudia Lima; KLEE, Antonia Espíndola Longoni. Os direitos do consumidor e a regulamentação do uso da internet no Brasil: convergência no direito às informações claras e completas nos contratos de prestação de serviços de internet. In: LEITE, George Salomão; LEMOS, Ronaldo (Coord.). Marco Civil da Internet. São Paulo: Atlas, 2014. p. 471-472.

${ }^{109}$ Art. 4º da Lei no ${ }^{\circ}$ 12.965/2014.

BRASIL. Lei no 12.965 , de 23 de abril de 2014. Estabelece princípios, garantias, direitos e deveres para o uso da Internet no Brasil. Disponível em: <http://www.planalto.gov.br/CCIVIL_03/_Ato2011-2014/2014/Lei/ L12965.htm>. Acesso em: 19 set. 2014.

${ }^{110}$ Art. 5o Para os efeitos desta Lei, considera-se:

I - internet: o sistema constituído do conjunto de protocolos lógicos, estruturado em escala mundial para uso público e irrestrito, com a finalidade de possibilitar a comunicação de dados entre terminais por meio de diferentes redes;

II - terminal: o computador ou qualquer dispositivo que se conecte à internet;

III - endereço de protocolo de internet (endereço IP): o código atribuído a um terminal de uma rede para permitir sua identificação, definido segundo parâmetros internacionais;

IV - administrador de sistema autônomo: a pessoa física ou jurídica que administra blocos de endereço IP específicos e o respectivo sistema autônomo de roteamento, devidamente cadastrada no ente nacional responsável pelo registro e distribuição de endereços IP geograficamente referentes ao País;

V - conexão à internet: a habilitação de um terminal para envio e recebimento de pacotes de dados pela internet, mediante a atribuição ou autenticação de um endereço IP;

VI - registro de conexão: o conjunto de informações referentes à data e hora de início e término de uma conexão à internet, sua duração e o endereço IP utilizado pelo terminal para o envio e recebimento de pacotes de dados;

VII - aplicações de internet: o conjunto de funcionalidades que podem ser acessadas por meio de um terminal conectado à internet; $\mathrm{e}$

VIII - registros de acesso a aplicações de internet: o conjunto de informações referentes à data e hora de uso de uma determinada aplicação de internet a partir de um determinado endereço IP.

BRASIL. Lei no 12.965, de 23 de abril de 2014. Estabelece princípios, garantias, direitos e deveres para o uso da Internet no Brasil. Disponível em: <http://www.planalto.gov.br/CCIVIL 03/ Ato2011-2014/2014/Lei/ L12965.htm>. Acesso em: 19 set. 2014.

${ }^{111}$ Art. $6^{\circ}$ da Lei no ${ }^{12.965 / 2014}$.

BRASIL. Lei oㅜ 12.965, de 23 de abril de 2014. Estabelece princípios, garantias, direitos e deveres para o uso da Internet no Brasil. Disponível em: <http://www.planalto.gov.br/CCIVIL 03/ Ato2011-2014/2014/Lei/ L12965.htm>. Acesso em: 19 set. 2014.

${ }^{112}$ Art. $7^{\circ} \mathrm{O}$ acesso à internet é essencial ao exercício da cidadania, e ao usuário são assegurados os seguintes direitos:

I - inviolabilidade da intimidade e da vida privada, sua proteção e indenização pelo dano material ou moral decorrente de sua violação; II - inviolabilidade e sigilo do fluxo de suas comunicações pela internet, salvo por ordem judicial, na forma da lei;

III - inviolabilidade e sigilo de suas comunicações privadas armazenadas, salvo por ordem judicial;

IV - não suspensão da conexão à internet, salvo por débito diretamente decorrente de sua utilização;

$\mathrm{V}$ - manutenção da qualidade contratada da conexão à internet;

VI - informações claras e completas constantes dos contratos de prestação de serviços, com detalhamento sobre o regime de proteção aos registros de conexão e aos registros de acesso a aplicações de internet, bem como sobre práticas de gerenciamento da rede que possam afetar sua qualidade;

VII - não fornecimento a terceiros de seus dados pessoais, inclusive registros de conexão, e de acesso a aplicações de internet, salvo mediante consentimento livre, expresso e informado ou nas hipóteses previstas em lei;

VIII - informações claras e completas sobre coleta, uso, armazenamento, tratamento e proteção de seus dados pessoais, que somente poderão ser utilizados para finalidades que:

a) justifiquem sua coleta;

b) não sejam vedadas pela legislação; e

c) estejam especificadas nos contratos de prestação de serviços ou em termos de uso de aplicações de internet;

IX - consentimento expresso sobre coleta, uso, armazenamento e tratamento de dados pessoais, que deverá ocorrer de forma destacada das demais cláusulas contratuais;

$X$ - exclusão definitiva dos dados pessoais que tiver fornecido a determinada aplicação de internet, a seu requerimento, ao término da relação entre as partes, ressalvadas as hipóteses de guarda obrigatória de registros previstas nesta Lei;

XI - publicidade e clareza de eventuais políticas de uso dos provedores de conexão à internet e de aplicações de internet;

XII - acessibilidade, consideradas as características físico-motoras, perceptivas, sensoriais, intelectuais e mentais do usuário, nos termos da lei; e

XIII - aplicação das normas de proteção e defesa do consumidor nas relações de consumo realizadas na internet".

BRASIL. Lei no 12.965 , de 23 de abril de 2014. Estabelece princípios, garantias, direitos e deveres para o uso da Internet no Brasil. Disponível em: <http://www.planalto.gov.br/CCIVIL_03/_Ato2011-2014/2014/Lei/ L12965.htm>. Acesso em: 19 set. 2014.

${ }^{113}$ OLIVEIRA, Carlos Eduardo Elias de. Aspectos principais da Lei $n^{\circ}$ 12.965, de 2014, o Marco Civil da Internet: subsídios à comunidade jurídica. Brasília: Núcleo de Estudos e Pesquisas/CONLEG/Senado, abr. 2014 (Texto para Discussão no 148). Disponível em: <http://www. senado.leg.br/estudos>. Acesso em: 29 abr. 2014.

${ }^{114}$ OLIVEIRA, Carlos Eduardo Elias de. Aspectos principais da Lei $n^{-}$ 12.965, de 2014, o Marco Civil da Internet: subsídios à comunidade 
jurídica. Brasília: Núcleo de Estudos e Pesquisas/CONLEG/Senado, abr. 2014 (Texto para Discussão no 148). Disponível em: <http://www. senado.leg.br/estudos>. Acesso em: 29 abr. 2014.

${ }^{115}$ O Marco Civil e a proteção dos seus dados pessoais: o que muda? Disponível em: <http://idgnow.com.br/blog/circuito/2014/04/29/omarco-civil-e-a-protecao-dos-seus-dados-pessoais-o-que-muda/>. Acesso em: 19 set. 2014.

${ }^{116}$ O Marco Civil e a proteção dos seus dados pessoais: o que muda? Disponível em: <http://idgnow.com.br/blog/circuito/2014/04/29/omarco-civil-e-a-protecao-dos-seus-dados-pessoais-o-que-muda/>. Acesso em: 19 set. 2014.

${ }^{117}$ O Marco Civil e a proteção dos seus dados pessoais: o que muda? Disponível em: <http://idgnow.com.br/blog/circuito/2014/04/29/omarco-civil-e-a-protecao-dos-seus-dados-pessoais-o-que-muda/>. Acesso em: 19 set. 2014.

${ }^{118}$ Sobre o tema, ver MARTINS, Guilherme Magalhães. O direito ao esquecimento na Internet. In: MARTINS, Guilherme Magalhães (Coord.). Direito privado e internet. São Paulo: Atlas, 2014. p. 3-28.

Ver, também: RODRIGUES JUNIOR, Otavio Luiz. Direito de apagar dados e a decisão do tribunal europeu no caso Google Espanha. Disponível em: <http://www.conjur.com.br/2014-mai-21/direito-apagardados-decisao-tribunal-europeu-google-espanha>. Acesso em: 19 set. 2014.

O texto continua em: RODRIGUES JUNIOR, Otávio Luiz. Direito de apagar dados e a decisão do tribunal europeu no caso Google Espanha (Parte 2). Disponível em: <http://www.conjur.com.br/2014-mai-28/ direito-comparado-direito-apagar-dados-decisao-tribunal-europeugoogle-espanha>. Acesso em: 19 set. 2014.

${ }^{119}$ O Marco Civil e a proteção dos seus dados pessoais: o que muda? Disponível em: < http://idgnow.com.br/blog/circuito/2014/04/29/omarco-civil-e-a-protecao-dos-seus-dados-pessoais-o-que-muda/ $>$. Acesso em: 19 set. 2014.

${ }^{120}$ Arts. 19 a 21 da Lei no ${ }^{-12.965 / 2014 . ~}$

${ }^{121}$ Art. 8o, caput, da Lei no ${ }^{\circ}$ 12.965/2014.

BRASIL. Lei no 12.965 , de 23 de abril de 2014. Estabelece princípios, garantias, direitos e deveres para o uso da Internet no Brasil. Disponível em: <http://www.planalto.gov.br/CCIVIL_03/_Ato2011-2014/2014/Lei/ L12965.htm>. Acesso em: 19 set. 2014.

${ }^{122}$ Art. $8^{\circ} \mathrm{A}$ garantia do direito à privacidade e à liberdade de expressão nas comunicações é condição para o pleno exercício do direito de acesso à internet.

Parágrafo único. São nulas de pleno direito as cláusulas contratuais que violem o disposto no caput, tais como aquelas que:

I - impliquem ofensa à inviolabilidade e ao sigilo das comunicações privadas, pela internet; ou

II - em contrato de adesão, não ofereçam como alternativa ao contratante a adoção do foro brasileiro para solução de controvérsias decorrentes de serviços prestados no Brasil.

BRASIL. Lei no 12.965, de 23 de abril de 2014. Estabelece princípios, garantias, direitos e deveres para o uso da Internet no Brasil. Disponível em: <http://www.planalto.gov.br/CCIVIL_03/_Ato2011-2014/2014/Lei/ L12965.htm>. Acesso em: 19 set. 2014.

${ }^{123}$ Conforme o art. 101 do CDC, que é objeto de atualização pelo PLS $281 / 2012$.

${ }^{124} \mathrm{O}$ Marco Civil e a proteção dos seus dados pessoais: o que muda? Disponível em: < http://idgnow.com.br/blog/circuito/2014/04/29/omarco-civil-e-a-protecao-dos-seus-dados-pessoais-o-que-muda/ $>$. Acesso em: 18 set. 2014

${ }^{125}$ Art. 10. A guarda e a disponibilização dos registros de conexão e de acesso a aplicações de internet de que trata esta Lei, bem como de dados pessoais e do conteúdo de comunicações privadas, devem atender à preservação da intimidade, da vida privada, da honra e da imagem das partes direta ou indiretamente envolvidas.

$\S 1$ o O provedor responsável pela guarda somente será obrigado a disponibilizar os registros mencionados no caput, de forma autônoma ou associados a dados pessoais ou a outras informações que possam contribuir para a identificação do usuário ou do terminal, mediante ordem judicial, na forma do disposto na Seção IV deste Capítulo, respeitado o disposto no art. $7^{\circ}$.

$\S 2^{\mathrm{o}} \mathrm{O}$ conteúdo das comunicações privadas somente poderá ser disponibilizado mediante ordem judicial, nas hipóteses e na forma que a lei estabelecer, respeitado o disposto nos incisos II e III do art. 7ㅇ․

$\S 3^{\circ} \mathrm{O}$ disposto no caput não impede o acesso aos dados cadastrais que informem qualificação pessoal, filiação e endereço, na forma da lei, pelas autoridades administrativas que detenham competência legal para a sua requisição.
$\S 4^{\circ}$ As medidas e os procedimentos de segurança e de sigilo devem ser informados pelo responsável pela provisão de serviços de forma clara e atender a padrões definidos em regulamento, respeitado seu direito de confidencialidade quanto a segredos empresariais.

BRASIL. Lei no 12.965 , de 23 abril de 2014. Estabelece princípios, garantias, direitos e deveres para o uso da Internet no Brasil. Disponível em: <http://www.planalto.gov.br/CCIVIL 03/ Ato2011-2014/2014/Lei/ L12965.htm>. Acesso em: 19 set. 2014.

${ }^{126} \mathrm{O}$ Marco Civil e a proteção dos seus dados pessoais: o que muda? Disponível em: <http://idgnow.com.br/blog/circuito/2014/04/29/omarco-civil-e-a-protecao-dos-seus-dados-pessoais-o-que-muda/ $>$. Acesso em: 19 set. 2014.

${ }^{127}$ Ver o seguinte julgado, no sentido de que basta a notificação extrajudicial para a remoção de conteúdo disponível na rede: "Agravo regimental no recurso especial. Civil e consumidor. Responsabilidade civil. Provedor de internet. Relação de consumo. Incidência do CDC. Provedor de conteúdo. Fiscalização prévia do teor das informações postadas no site pelos usuários. Dano moral. Risco inerente ao negócio. Ciência da existência de conteúdo ilícito. Utilização pelo lesado da ferramenta de denúncia disponibilizada pelo próprio provedor. Falha na prestação do serviço. Quantum arbitrado com razoabilidade. Súmulas 7 e 83 do STJ. Agravo regimental desprovido". BRASIL. Superior Tribunal de Justiça. Terceira Turma, Agravo Regimental no Recurso Especial no 1.325.220/ MG, Relator Ministro Paulo de Tarso Vieira Sanseverino, julgado em 18 jun. 2013.

Ver, também: BRASIL. Superior Tribunal de Justiça. Terceira Turma, Recurso Especial n⿳⺈ 1.308.830/RS, Relatora Ministra Nancy Andrighi, julgado em 8 maio 2012.

Da mesma forma, ver: BRASIL. Superior Tribunal de Justiça. Terceira Turma, Recurso Especial no 1.323.754/RJ, Relatora Ministra Nancy Andrighi, julgado em 19 jun. 2012, cuja ementa é: "Responsabilidade civil. Internet. Redes sociais. Mensagem ofensiva. Ciência pelo provedor. Remoção. Prazo. 1. A velocidade com que as informações circulam no meio virtual torna indispensável que medidas tendentes a coibir a divulgação de conteúdos depreciativos e aviltantes sejam adotadas célere e enfaticamente, de sorte a potencialmente reduzir a disseminação do insulto, minimizando os nefastos efeitos inerentes a dados dessa natureza. 2. Uma vez notificado de que determinado texto ou imagem possui conteúdo ilícito, o provedor deve retirar o material do ar no prazo de 24 (vinte e quatro) horas, sob pena de responder solidariamente com o autor direto do dano, em virtude da omissão praticada. 3. Nesse prazo de 24 horas, não está o provedor obrigado a analisar o teor da denúncia recebida, devendo apenas promover a suspensão preventiva das respectivas páginas, até que tenha tempo hábil para apreciar a veracidade das alegações, de modo a que, confirmando-as, exclua definitivamente o perfil ou, tendo-as por infundadas, restabeleça o seu livre acesso. 4. O diferimento da análise do teor das denúncias não significa que o provedor poderá postergá-la por tempo indeterminado, deixando sem satisfação o usuário cujo perfil venha a ser provisoriamente suspenso. Cabe ao provedor, o mais breve possível, dar uma solução final para o conflito, confirmando a remoção definitiva da página de conteúdo ofensivo ou, ausente indício de ilegalidade, recolocando-a no ar, adotando, nessa última hipótese, as providências legais cabíveis contra os que abusarem da prerrogativa de denunciar. 5. Recurso especial a que se nega provimento".

${ }^{128}$ O Marco Civil e a proteção dos seus dados pessoais: o que muda? Disponível em: <http://idgnow.com.br/blog/circuito/2014/04/29/omarco-civil-e-a-protecao-dos-seus-dados-pessoais-o-que-muda/ $>$. Acesso em: 19 set. 2014.

${ }^{129}$ Art. 11. Em qualquer operação de coleta, armazenamento, guarda e tratamento de registros, de dados pessoais ou de comunicações por provedores de conexão e de aplicações de internet em que pelo menos um desses atos ocorra em território nacional, deverão ser obrigatoriamente respeitados a legislação brasileira e os direitos à privacidade, à proteção dos dados pessoais e ao sigilo das comunicações privadas e dos registros. $\S 1$ o O disposto no caput aplica-se aos dados coletados em território nacional e ao conteúdo das comunicações, desde que pelo menos um dos terminais esteja localizado no Brasil.

$\S 2^{\circ} \mathrm{O}$ disposto no caput aplica-se mesmo que as atividades sejam realizadas por pessoa jurídica sediada no exterior, desde que oferte serviço ao público brasileiro ou pelo menos uma integrante do mesmo grupo econômico possua estabelecimento no Brasil.

$\S 3^{\circ}$ Os provedores de conexão e de aplicações de internet deverão prestar, na forma da regulamentação, informações que permitam a verificação quanto ao cumprimento da legislação brasileira referente à coleta, à guarda, ao armazenamento ou ao tratamento de dados, bem como quanto ao respeito à privacidade e ao sigilo de comunicações. 
§ 4º Decreto regulamentará o procedimento para apuração de infrações ao disposto neste artigo.

BRASIL. Lei $\mathrm{n}^{\mathrm{o}}$ 12.965, de 23 abril de 2014. Estabelece princípios, garantias, direitos e deveres para o uso da Internet no Brasil. Disponível em: <http://www.planalto.gov.br/CCIVIL 03/ Ato2011-2014/2014/Lei/ L12965.htm>. Acesso em: 19 set. 2014.

${ }^{130}$ Art. 12. Sem prejuízo das demais sanções cíveis, criminais ou administrativas, as infrações às normas previstas nos arts. 10 e 11 ficam sujeitas, conforme o caso, às seguintes sanções, aplicadas de forma isolada ou cumulativa:

I - advertência, com indicação de prazo para adoção de medidas corretivas;

II - multa de até $10 \%$ (dez por cento) do faturamento do grupo econômico no Brasil no seu último exercício, excluídos os tributos, considerados a condição econômica do infrator e o princípio da proporcionalidade entre a gravidade da falta e a intensidade da sanção;

III - suspensão temporária das atividades que envolvam os atos previstos no art. 11; ou

IV - proibição de exercício das atividades que envolvam os atos previstos no art. 11.

Parágrafo único. Tratando-se de empresa estrangeira, responde solidariamente pelo pagamento da multa de que trata o caput sua filial, sucursal, escritório ou estabelecimento situado no País.

BRASIL. Lei no 12.965, de 23 abril de 2014. Estabelece princípios, garantias, direitos e deveres para o uso da Internet no Brasil. Disponível em: <http://www.planalto.gov.br/CCIVIL_03/_Ato2011-2014/2014/Lei/ L12965.htm>. Acesso em: 19 set. 2014.

${ }^{131}$ LORENZETTI, Ricardo Luis. Comércio eletrônico. Tradução de Fabiano Menke. Notas de Claudia Lima Marques. São Paulo: Revista dos Tribunais, 2004. p. 370.

${ }^{132}$ ONU. Assembleia Geral. Promotion and Protection of all Human Rights, Civil, Political, Economic, Social and Cultural Rights, Including the Right to Development: The Promotion, Protection and Enjoyment of Human Rights on the Internet. $A / H R C / 20 / L .13,29.6 .2013$. Disponível em: <http://www.regeringen.se/content/1/c6/19/64/51/6999c512.pdf>. Acesso em: 8 maio 2014.

Ver MARQUES, Claudia Lima; KLEE, Antonia Espíndola Longoni. Os direitos do consumidor e a regulamentação do uso da internet no Brasil: convergência no direito às informações claras e completas nos contratos de prestação de serviços de internet. In: LEITE, George Salomão; LEMOS, Ronaldo (Coord.). Marco Civil da Internet. São Paulo: Atlas, 2014. p. $510-511$.

${ }^{133}$ Anteprojeto de Lei de Proteção de Dados Pessoais. Disponível em: $<$ http://www.acessoainformacao.gov.br/menu-de-apoio/recursos-passoa-passo/anteprojeto-lei-protecao-dados-pessoais.pdf>. Acesso em: 19 set. 2014.

${ }^{134}$ O Marco Civil e a proteção dos seus dados pessoais: o que muda? Disponível em: <http://idgnow.com.br/blog/circuito/2014/04/29/omarco-civil-e-a-protecao-dos-seus-dados-pessoais-o-que-muda/>. Acesso em: 19 set. 2014.

Ver, também, MENDES, Laura Schertel. O direito fundamental à proteção de dados pessoais. Revista de Direito do Consumidor, São Paulo, ano 20, n. 79, p. 45, jul.-set. 2011.

Da mesma forma, DONEDA, Danilo. Da privacidade à proteção de dados pessoais. Rio de Janeiro: Renovar, 2006.

${ }^{135} \mathrm{O}$ Marco Civil e a proteção dos seus dados pessoais: o que muda? Disponível em: <http://idgnow.com.br/blog/circuito/2014/04/29/omarco-civil-e-a-protecao-dos-seus-dados-pessoais-o-que-muda/ $>$. Acesso em: 19 set. 2014.

${ }^{136}$ O Marco Civil e a proteção dos seus dados pessoais: o que muda? Disponível em: <http://idgnow.com.br/blog/circuito/2014/04/29/omarco-civil-e-a-protecao-dos-seus-dados-pessoais-o-que-muda/>. Acesso em: 19 set. 2014.

${ }^{137}$ CARVALHO, Ana Paula Gambogi. O consumidor e o direito à autodeterminação informacional: considerações sobre os bancos de dados eletrônicos. In: NERY JUNIOR, Nelson; NERY, Rosa Maria de Andrade (Org.). Responsabilidade civil: direito à informação: dever de informação, informações cadastrais, mídia, informação e poder, internet. São Paulo: Revista dos Tribunais, 2010. v. 8. (Doutrinas essenciais). p. 359-360.

${ }^{138}$ O Marco Civil e a proteção dos seus dados pessoais: o que muda? Disponível em: <http://idgnow.com.br/blog/circuito/2014/04/29/omarco-civil-e-a-protecao-dos-seus-dados-pessoais-o-que-muda/>. Acesso em: 19 set. 2014.

Ver, também: Anteprojeto de Lei de Proteção de Dados Pessoais. Disponível em: <http://www.acessoainformacao.gov.br/menu-de-apoio/ recursos-passo-a-passo/anteprojeto-lei-protecao-dados-pessoais.pdf . Acesso em: 19 set. 2014.

${ }^{139} \mathrm{O}$ Marco Civil e a proteção dos seus dados pessoais: o que muda? Disponível em: <http://idgnow.com.br/blog/circuito/2014/04/29/omarco-civil-e-a-protecao-dos-seus-dados-pessoais-o-que-muda/>. Acesso em: 19 set. 2014.

${ }^{140}$ MENDES, Laura Schertel. Segurança da informação, proteção de dados pessoais e confiança. Revista de Direito do Consumidor, São Paulo, ano 22, n. 90, p. 256, nov.-dez. 2013.

${ }^{141}$ MENDES, Laura Schertel. Segurança da informação, proteção de dados pessoais e confiança. Revista de Direito do Consumidor, São Paulo, ano 22, n. 90, p. 256, nov.-dez. 2013.

${ }^{142}$ Anteprojeto de Lei de Proteção de Dados Pessoais. Disponível em: $<$ http://www.acessoainformacao.gov.br/menu-de-apoio/recursos-passoa-passo/anteprojeto-lei-protecao-dados-pessoais.pdf>. Acesso em: 19 set. 2014.

${ }^{143}$ Art. $1^{\text {OO }}$ do Anteprojeto de Lei sobre a Proteção de Dados Pessoais. Esta lei tem por objetivo garantir e proteger, no âmbito do tratamento de dados pessoais, a dignidade e os direitos fundamentais da pessoa, particularmente em relação à sua liberdade, igualdade e privacidade pessoal e familiar, nos termos do art. $5^{\circ}$, incisos X e XII da Constituição Federal. Disponível em: <http://www.acessoainformacao.gov.br/ menu-de-apoio/recursos-passo-a-passo/anteprojeto-lei-protecao-dadospessoais.pdf >. Acesso em: 19 set. 2014.

${ }^{144}$ Anteprojeto de Lei de Proteção de Dados Pessoais. Disponível em: $<$ http://www.acessoainformacao.gov.br/menu-de-apoio/recursos-passoa-passo/anteprojeto-lei-protecao-dados-pessoais.pdf > . Acesso em: 19 set. 2014.

${ }^{145}$ Art. $3^{\circ}$ do Anteprojeto de Lei de Proteção de Dados Pessoais. A presente lei aplica-se aos tratamentos de dados pessoais realizados no território nacional por pessoa física ou jurídica de direito público ou privado, ainda que o banco de dados seja localizado no exterior.

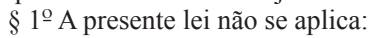

I - ao tratamento de dados pessoais realizado por pessoa física para fins exclusivamente pessoais e domésticos, desde que os dados tratados não sejam destinados à comunicação;

II - aos bancos de dados utilizados para o exercício da atividade jornalística e exclusivamente para tal fim.

$\S 2$ o Os bancos de dados instituídos e mantidos para fins exclusivos de segurança pública, defesa, segurança do Estado e suas atividades de investigação e repressão de delitos serão regidos por legislação específica.

Anteprojeto de Lei de Proteção de Dados Pessoais. Disponível em: $<$ http://www.acessoainformacao.gov.br/menu-de-apoio/recursos-passoa-passo/anteprojeto-lei-protecao-dados-pessoais.pdf>. Acesso em: 19 set. 2014.

${ }^{146}$ Art. $4^{\circ}$ do Anteprojeto de Lei de Proteção de Dados Pessoais. Para os fins da presente lei, entende-se como:

I - dado pessoal: qualquer informação relativa a uma pessoa identificada ou identificável, direta ou indiretamente, incluindo todo endereço ou número de identificação de um terminal utilizado para conexão a uma rede de computadores; [...].

Anteprojeto de Lei de Proteção de Dados Pessoais. Disponível em: $<$ http://www.acessoainformacao.gov.br/menu-de-apoio/recursos-passoa-passo/anteprojeto-lei-protecao-dados-pessoais.pdf>. Acesso em: 19 set. 2014.

${ }^{147}$ Art. 4으, II - tratamento: toda operação ou conjunto de operações, realizadas com ou sem o auxílio de meios automatizados, que permita a coleta, armazenamento, ordenamento, conservação, modificação, comparação, avaliação, organização, seleção, extração, utilização, bloqueio e cancelamento de dados pessoais, bem como o seu fornecimento a terceiros por meio de transferência, comunicação ou interconexão; [...]. Anteprojeto de Lei de Proteção de Dados Pessoais. Disponível em: $<$ http://www.acessoainformacao.gov.br/menu-de-apoio/recursos-passoa-passo/anteprojeto-lei-protecao-dados-pessoais.pdf $>$. Acesso em: 19 set. 2014

${ }^{148}$ Art. 4⿳㇒一八, III - banco de dados: todo conjunto estruturado de dados pessoais, localizado em um ou vários locais, em meio eletrônico ou não; [...]. Anteprojeto de Lei de Proteção de Dados Pessoais. Disponível em: $<$ http://www.acessoainformacao.gov.br/menu-de-apoio/recursos-passoa-passo/anteprojeto-lei-protecao-dados-pessoais.pdf $>$. Acesso em: 19 set. 2014.

${ }^{149}$ Art. 4o, IV - dados sensíveis: dados pessoais cujo tratamento possa ensejar discriminação do titular, tais como aqueles que revelem a origem racial ou étnica, as convicções religiosas, filosóficas ou morais, as opiniões políticas, a filiação sindical, partidária ou a organizações de 
caráter religioso, filosófico ou político, os referentes à saúde e à vida sexual, bem como os dados genéticos e biométricos; [...].

Anteprojeto de Lei de Proteção de Dados Pessoais. Disponível em: $<$ http://www.acessoainformacao.gov.br/menu-de-apoio/recursos-passoa-passo/anteprojeto-lei-protecao-dados-pessoais.pdf>. Acesso em: 19 set. 2014.

${ }^{150}$ Art. 4º, XIV - dados anônimos: dados relativos a um titular que não possa ser identificado, nem pelo responsável pelo tratamento nem por qualquer outra pessoa, tendo em conta o conjunto de meios suscetíveis de serem razoavelmente utilizados pelo responsável pelo tratamento dos dados ou por qualquer outra pessoa para identificar o referido titular.

Anteprojeto de Lei de Proteção de Dados Pessoais. Disponível em: $<$ http://www.acessoainformacao.gov.br/menu-de-apoio/recursos-passoa-passo/anteprojeto-lei-protecao-dados-pessoais.pdf>. Acesso em: 19 set. 2014.

${ }^{151}$ Art. $4^{\mathrm{O}}[\ldots]$.

V - titular: pessoa física a quem se referem os dados pessoais que são objeto de tratamento nos termos desta lei;

VI - responsável: a pessoa física ou jurídica, de direito público ou privado, a quem competem as decisões referentes às finalidades e modalidades de tratamento de dados pessoais;

VII - subcontratado: a pessoa jurídica contratada pelo responsável pelo banco de dados como encarregado do tratamento de dados pessoais;

VIII - comunicação: ato de revelar dados pessoais a um ou mais sujeitos determinados diversos do seu titular, sob qualquer forma;

IX - difusão: ato de revelar dados pessoais a um ou mais sujeitos indeterminados diversos do seu titular, sob qualquer forma;

$\mathrm{X}$ - interconexão: transferência de dados de um banco de dados a outro, mantido ou não pelo mesmo proprietário, com finalidade semelhante ou distinta;

XI - bloqueio: a conservação do dado pessoal ou do banco de dados com a suspensão temporária de qualquer operação de tratamento;

XII - cancelamento: a eliminação ou destruição de dados ou conjunto de dados armazenados em banco de dados, seja qual for o procedimento empregado;

XIII - dissociação: ato de modificar o dado pessoal de modo a que ele não possa ser associado, direta ou indiretamente, com um indivíduo identificado ou identificável;

[...].

Anteprojeto de Lei de Proteção de Dados Pessoais. Disponível em: <http:// www.acessoainformacao.gov.br/menu-de-apoio/recursos-passo-a-passo/ anteprojeto-lei-protecao-dados-pessoais.pdf $>$. Acesso em: 19 set. 2014.

${ }^{152}$ Anteprojeto de Lei de Proteção de Dados Pessoais. Disponível em: $<$ http://www.acessoainformacao.gov.br/menu-de-apoio/recursos-passoa-passo/anteprojeto-lei-protecao-dados-pessoais.pdf>. Acesso em: 19 set. 2014.

${ }^{153}$ Anteprojeto de Lei de Proteção de Dados Pessoais. Disponível em: $<$ http://www.acessoainformacao.gov.br/menu-de-apoio/recursos-passoa-passo/anteprojeto-lei-protecao-dados-pessoais.pdf>. Acesso em: 19 set. 2014.

${ }^{154}$ Anteprojeto de Lei de Proteção de Dados Pessoais. Disponível em: $<$ http://www.acessoainformacao.gov.br/menu-de-apoio/recursos-passoa-passo/anteprojeto-lei-protecao-dados-pessoais.pdf> . Acesso em: 19 set. 2014.

${ }^{155}$ Art. $8^{\circ}$ Os responsáveis pelo tratamento de dados pessoais deverão atender, dentre outros, aos seguintes princípios gerais de proteção de dados pessoais:

I - Princípio da finalidade: a não utilização dos dados pessoais objeto de tratamento para finalidades distintas ou incompatíveis com aquelas que fundamentaram a sua coleta e que tenham sido informadas ao titular; bem como a limitação deste tratamento às finalidades determinadas, explícitas e legítimas do responsável;

II - Princípio da necessidade: a limitação da utilização de dados pessoais ao mínimo necessário, de forma a excluir o seu tratamento sempre que a finalidade que se procura atingir possa ser igualmente realizada com a utilização de dados anônimos ou com o recurso a meios que permitam a identificação do interessado somente em caso de necessidade;

III - Princípio do livre acesso: a possibilidade de consulta gratuita, pelo titular, de seus dados pessoais, bem como de suas modalidades de tratamento;

IV - Princípio da proporcionalidade: o tratamento de dados pessoais apenas nos casos em que houver relevância e pertinência em relação à finalidade para a qual foram coletados;

V - Princípio da qualidade dos dados: a exatidão dos dados pessoais objeto de tratamento, com atualização realizada segundo a periodicidade necessária para o cumprimento da finalidade de seu tratamento;
VI - Princípio da transparência: a informação ao titular sobre a realização do tratamento de seus dados pessoais, com indicação da sua finalidade, categorias de dados tratados, período de conservação destes e demais informações relevantes;

VII - Princípio da segurança física e lógica: o uso, pelo responsável pelo tratamento de dados, de medidas técnicas e administrativas proporcionais ao atual estado da tecnologia, à natureza dos dados e às características específicas do tratamento, constantemente atualizadas e aptas a proteger os dados pessoais sob sua responsabilidade da destruição, perda, alteração e difusão, acidentais ou ilícitas, ou do acesso não autorizado;

VIII - Princípio da boa-fé objetiva: o respeito à lealdade e à boa-fé objetiva no tratamento de dados pessoais;

IX - Princípio da responsabilidade: a reparação, nos termos da lei, dos danos causados aos titulares dos dados pessoais, sejam estes patrimoniais ou morais, individuais ou coletivos;

$\mathrm{X}$ - Princípio da prevenção: o dever do responsável de, para além das disposições específicas desta Lei, adotar, sempre que possível, medidas capazes de prevenir a ocorrência de danos em virtude do tratamento de dados pessoais.

Anteprojeto de Lei de Proteção de Dados Pessoais. Disponível em: $<$ http:// www.acessoainformacao.gov.br/menu-de-apoio/recursos-passo-a-passo/ anteprojeto-lei-protecao-dados-pessoais.pdf $>$. Acesso em: 16 set. 2014.

${ }^{156}$ Art. 9- $\mathrm{O}$ tratamento de dados pessoais somente pode ocorrer após o consentimento livre, expresso e informado do titular, que poderá ser dado por escrito ou por outro meio que o certifique, após a notificação prévia ao titular das informações constantes no art. 11.

$\S 1^{\circ}$ Nos serviços de execução continuada, o consentimento deverá ser renovado periodicamente, nos termos do regulamento.

$\S 2^{\mathrm{O}} \mathrm{O}$ tratamento de dados pessoais de crianças somente será possível com o consentimento dos responsáveis legais e no seu melhor interesse, sendo vedada a utilização destes dados para finalidades comerciais.

Anteprojeto de Lei de Proteção de Dados Pessoais. Disponível em: $<\mathrm{http}$ ://www.acessoainformacao.gov.br/menu-de-apoio/recursos-passoa-passo/anteprojeto-lei-protecao-dados-pessoais.pdf>. Acesso em: 16 set. 2014.

${ }^{157}$ Art. 11. No momento da coleta de dados pessoais, o titular será informado de forma clara e explícita sobre:

I - a finalidade para a qual os seus dados pessoais estão sendo coletados e de que forma serão tratados;

II - a identidade e o domicílio do responsável pelo tratamento;

III - a natureza obrigatória ou facultativa do fornecimento dos dados;

IV - as consequências de uma eventual negativa em fornecê-los;

$\mathrm{V}$ - os sujeitos para os quais os dados podem ser comunicados e o seu âmbito de difusão; e

VI - os seus direitos, em particular da possibilidade de negar-se a fornecer os dados pessoais e sobre o seu direito de acesso e retificação gratuitos.

Parágrafo único. Considera-se nulo o consentimento prestado caso as referidas informações tenham conteúdo enganoso ou não tenham sido fornecidas de forma clara e explícita.

Anteprojeto de Lei de Proteção de Dados Pessoais. Disponível em: $<$ http://www.acessoainformacao.gov.br/menu-de-apoio/recursos-passoa-passo/anteprojeto-lei-protecao-dados-pessoais.pdf>. Acesso em: 16 set. 2014

${ }^{158}$ Art. 10. O consentimento pode ser revogado a qualquer momento.

Anteprojeto de Lei de Proteção de Dados Pessoais. Disponível em: $<$ http://www.acessoainformacao.gov.br/menu-de-apoio/recursos-passoa-passo/anteprojeto-lei-protecao-dados-pessoais.pdf>. Acesso em: 16 set. 2014.

${ }^{159}$ Art. 12. O consentimento, caso prestado em conjunto com outras declarações, deve figurar de forma expressa e apartada.

Anteprojeto de Lei de Proteção de Dados Pessoais. Disponível em: $<$ http://www.acessoainformacao.gov.br/menu-de-apoio/recursos-passoa-passo/anteprojeto-lei-protecao-dados-pessoais.pdf>. Acesso em: 16 set. 2014

${ }^{160}$ Art. 13. O consentimento será dispensado quando o tratamento: I - for necessário para a execução de obrigações derivadas de um contrato do qual é parte o titular, para a execução de procedimentos précontratuais requeridos por este, ou para o cumprimento de uma obrigação legal por parte do responsável;

II - referir-se a dados provenientes de registros, atos ou documentos públicos de acesso público irrestrito;

III - for necessário para o exercício de funções próprias dos poderes do Estado;

IV - for realizado unicamente com finalidades de pesquisa histórica, científica ou estatística; 
V - for necessário para a proteção da vida ou da incolumidade física do titular ou de um terceiro, nos casos em que o titular não possa prestar o próprio consentimento por impossibilidade física ou por incapacidade de compreensão;

VI - for necessário para o exercício do direito de defesa ou para fazer valer um direito em sede judicial, desde que os dados coletados sejam tratados exclusivamente para esta finalidade e estritamente pelo período de tempo necessário para sua execução;

VII - disser respeito a dados sobre o inadimplemento de obrigações por parte do titular, caso em que o titular deverá ser notificado previamente por escrito, nos termos do art. 43 da Lei 8.078/90 - Código de Defesa do Consumidor.

Anteprojeto de Lei de Proteção de Dados Pessoais. Disponível em: $<$ http://www.acessoainformacao.gov.br/menu-de-apoio/recursos-passoa-passo/anteprojeto-lei-protecao-dados-pessoais.pdf $>$. Acesso em: 16 set. 2014.

${ }^{161}$ Art. 14. Os dados pessoais que forem objeto de tratamento deverão ser: I - tratados de forma lícita e com boa-fé;

II - coletados e armazenados para finalidades determinadas, explícitas e legítimas;

III - exatos, claros, objetivos, atualizados e de fácil compreensão;

IV - pertinentes, completos, proporcionais e não excessivos em relação à finalidade que justificou sua coleta ou tratamento posterior;

$\mathrm{V}$ - conservados de forma a permitir a identificação de seu titular por um período de tempo não superior ao necessário para as finalidades que justificaram sua coleta ou tratamento posterior; e

VI - conservados por período não superior ao estabelecido em lei ou regulamento específico para cada setor.

$\S 1^{\mathrm{O}}$ É vedado o tratamento de dados pessoais obtidos por meio de erro, dolo, coação e lesão.

$\S 2^{\circ}$ Os dados pessoais obtidos ou tratados de forma contrária à presente lei e à disciplina referente à proteção de dados não poderão ser utilizados e deverão ser cancelados.

Anteprojeto de Lei de Proteção de Dados Pessoais. Disponível em: $<$ http://www.acessoainformacao.gov.br/menu-de-apoio/recursos-passoa-passo/anteprojeto-lei-protecao-dados-pessoais.pdf $>$. Acesso em: 16 set. 2014.

${ }^{162}$ Art. 28 do Anteprojeto de Lei de Proteção de Dados Pessoais. Anteprojeto de Lei de Proteção de Dados Pessoais. Disponível em: <http:// www.acessoainformacao.gov.br/menu-de-apoio/recursos-passo-a-passo/ anteprojeto-lei-protecao-dados-pessoais.pdf>. Acesso em: 16 set. 2014.
${ }^{163}$ Art. 29 do Anteprojeto de Lei de Proteção de Dados Pessoais. Anteprojeto de Lei de Proteção de Dados Pessoais. Disponível em: $<$ http://www.acessoainformacao.gov.br/menu-de-apoio/recursos-passoa-passo/anteprojeto-lei-protecao-dados-pessoais.pdf $>$. Acesso em: 16 set. 2014.

${ }^{164}$ Art. 30. Os dados pessoais serão cancelados quando deixarem de ser necessários ou pertinentes para a finalidade que justificou sua coleta e tratamento.

Parágrafo único. Lei ou regulamento poderá dispor sobre períodos máximos para o tratamento de dados pessoais em setores e situações específicas.

Anteprojeto de Lei de Proteção de Dados Pessoais. Disponível em: $<$ http://www.acessoainformacao.gov.br/menu-de-apoio/recursos-passoa-passo/anteprojeto-lei-protecao-dados-pessoais.pdf>. Acesso em: 16 set. 2014.

${ }^{165}$ Código de Ética da ABEMD. Disponível em: < http://www.abemd.org.br/ pagina.php? $\mathrm{id}=23>$. Acesso em: 19 set. 2014.

${ }^{166}$ Código de Ética da ABEMD. Disponível em: < http://www.abemd.org.br/ pagina.php? $\mathrm{id}=23>$. Acesso em: 19 set. 2014.

${ }^{167}$ Código de Ética da ABEMD. Disponível em: < http://www.abemd.org.br/ pagina.php? $\mathrm{id}=23>$. Acesso em: 19 set. 2014.

${ }^{168}$ Código de Ética da ABEMD. Disponível em: < http://www.abemd.org.br/ pagina.php?id=23>. Acesso em: 19 set. 2014.

${ }^{169}$ MENDES, Laura Schertel. Segurança da informação, proteção de dados pessoais e confiança. Revista de Direito do Consumidor, São Paulo, ano 22, n. 90, p. 257, nov.-dez. 2013.

${ }^{170} \mathrm{O}$ Marco Civil e a proteção dos seus dados pessoais: o que muda? Disponível em: <http://idgnow.com.br/blog/circuito/2014/04/29/omarco-civil-e-a-protecao-dos-seus-dados-pessoais-o-que-muda/ $>$. Acesso em: 19 set. 2014.

${ }^{171}$ O Marco Civil e a proteção dos seus dados pessoais: o que muda? Disponível em: <http://idgnow.com.br/blog/circuito/2014/04/29/omarco-civil-e-a-protecao-dos-seus-dados-pessoais-o-que-muda/ $>$. Acesso em: 19 set. 2014.

${ }^{172} \mathrm{O}$ Marco Civil e a proteção dos seus dados pessoais: o que muda? Disponível em: <http://idgnow.com.br/blog/circuito/2014/04/29/omarco-civil-e-a-protecao-dos-seus-dados-pessoais-o-que-muda/ $>$. Acesso em: 19 set. 2014.

${ }^{173}$ MENDES, Laura Schertel. O direito fundamental à proteção de dados pessoais. Revista de Direito do Consumidor, São Paulo, ano 20, n. 79, p. 45 , jul.-set. 2011. 